\title{
Shedding light on the larval genus Eretmocaris: morphological larval features of two closely related trans-isthmian Lysmata species (Decapoda: Caridea: Hippolytidae) described on the basis of laboratory cultured material
}

\author{
Cátia Bartilotti · Ricardo Calado $\cdot$ Andrew Rhyne • \\ Antonina dos Santos
}

Received: 05 March 2010 / Revised: 25 February 2011 / Accepted: 04 March 2011 / Published online: 8 April 2011

(C) Springer-Verlag and AWI 2011

\begin{abstract}
Complete larval series are known for only three of the 39 valid species worldwide in the genus Lysmata. The present work deals with the larval development of two closely related trans-isthmian species of Lysmata, L. galapagensis (eastern Pacific Ocean), and L. moorei (southwestern Atlantic Ocean), using laboratory cultured material. The morphological features of the first four zoeal stages of both species, the fifth to seventh stages of L. galapagensis, and the last stage of L. moorei are described and compared with the larval descriptions currently available for the genus. Larvae of both species hatch with a similar form to L. seticaudata, with their first and fifth pereiopods as buds, and show a very steady development of their morphological characters. The zoeal characters match the phylogenetic results currently available for the genus Lysmata and L. galapagensis, L. moorei and L. seticaudata belong to the same monophyletic clade. We hypothesize that the
\end{abstract}

Communicated by H.-D. Franke.

C. Bartilotti $(\bowtie) \cdot$ A. dos Santos

Instituto Nacional de Recursos Biológicos-IPIMAR,

Av. de Brasília, s/n, 1449-006 Lisbon, Portugal

e-mail: cbartilotti@ipimar.pt

R. Calado

CESAM - Centre for Environmental and Marine Studies, Department of Biology, University of Aveiro,

Campus Universitário de Santiago, 3810-193 Aveiro, Portugal

A. Rhyne

Department of Biology and Marine Biology,

Roger Williams University, One Old Ferry Road,

Bristol, RI 02809, USA

\section{A. Rhyne}

Research Department, New England Aquarium,

One Central Wharf, Boston, MA 02110, USA larvae of all species within this clade will hatch with the first and fifth pereiopods as buds and will present a maximum of nine zoeal stages. The relationships between the studied material and the composite larval genus Eretmocaris are discussed, with emphasis on Eretmocaris corniger which has an extremely long rostrum and a spine on the dorsal surface of the third pleomere, characters also recorded in L. galapagensis. The larval forms earlier described as the tropical eastern Pacific E. corniger are matched to a known Lysmata species, L. galapagensis. The identity of E. corniger larvae recorded one century ago from the tropical eastern Atlantic is also discussed.

Keywords Decapoda $\cdot$ Hippolytidae $\cdot$ Lysmata galapagensis · Lysmata moorei - Larval development . Eretmocaris $\cdot$ Biogeography

\section{Introduction}

In recent years, caridean shrimps of the genus Lysmata have become extremely popular in the marine aquarium industry and have reached high market prices (Calado et al. 2003a; Calado 2008). Presently, there are 39 valid species in the genus (Anker et al. 2009; Baeza et al. 2009a; Laubenheimer and Rhyne 2010), ranging in distribution from tropical coral reefs to rocky shores in warm-temperate waters (Debelius 2001).

Lysmata culture efforts have provided an excellent opportunity to increase the knowledge on its ecology and reproductive biology. Given the key role of larviculture for the successful production of Lysmata in captivity, there is surprisingly little information published on their larval development and morphology. Apart from the work by Calado et al. (2004), with the redescription of the larval 
stages of L. seticaudata, the complete larval morphology and development patterns are only known for two more species of Lysmata, L. ensirostris (Pillai 1974) and what Kurata (1970) referred to as $L$. wurdemanni (adult species identity is impossible to determine). The knowledge of the morphological changes during larval development is crucial to understand phylogenetic relationships (e.g. Clark 2009), geographical differentiation (e.g. Schubart et al. 2005), and ecology (e.g. Levin 2006).

The genus Eretmocaris was created by Bate (1888) who distinguished four larval types, E. remipes, E. longicaulis, E. stylorostris, and E. corniger. All these larvae shared a common and remarkable morphological feature: a long and slender ocular peduncle. When studying the larvae of L. seticaudata (Risso, 1816), Caroli (1918) acknowledged their similarity with Eretmocaris larvae and hypothesized that they could be the larval forms of two or more caridean shrimp genera, including Lysmata Risso, 1816. Gurney (1937) conclusively demonstrated that the marked elongation of the eyestalks as well as the precocious development of leg 5 (prior to the appearance of legs 3 and 4) into an enormously long appendage with a paddle-like enlargement of the propodus in Eretmocaris specimens are in fact larval features displayed by hippolytid shrimp of the genus Lysmata and allied genera such as Exhippolysmata Stebbing, 1915 and Lysmatella Borradaile, 1915. Although the status of Eretmocaris has never been validated, the name continued to be used by researchers to classify larval forms from the plankton, which present the above characters (e.g. Lindley et al. 2002; Brightdoom et al. 2006).

One of the most remarkable types of Eretmocaris is certainly E. corniger. This larval form displays morphological characters unique among known Eretmocaris, namely a prominent spine on dorsal surface of the third pleomere, and a remarkably long rostrum with several dorsal teeth (Gurney 1937). Gopalakrishnan and Laurs (1971) described several larval specimens from the eastern tropical Pacific as E. corniger and suggested a relationship between their occurrences and the eastern ocean tropical islands. The adult form of Lysmata corresponding to E. corniger larvae remained unknown, both from the Atlantic and the Pacific Oceans, and so far, no species of Lysmata has been reported to occur in both of these oceans.

The molecular phylogeny of Lysmata has been recently studied by several authors (Baeza et al. 2009b; Baeza 2010; Fiedler et al. 2010). Baeza et al. (2009b) and Baeza (2010) presented the molecular phylogeny of the genus based on a segment of the 16S rRNA mitochondrial DNA. The tree topology obtained by Baeza (2010) recognizes three of the main subclades previously obtained by Baeza et al. (2009b), partially supports the separation of species according to the development of the accessory branch of the outer antennular flagellum into two different genera or subgenera, and shows that the monophyletic clade comprised by species of Lysmata and Exhippolysmata is divided into 4 subclades: the "Tropical American Clade", the "Cleaner Clade", the "Cosmopolitan Clade", and the "Morpho-variable Clade". Fiedler et al. (2010) presents the mitochondrial (16S) and the nuclear ribosomal (28S rRNA) phylogeny of the genus, which supports the historical morphological division of Lysmata into three clades, based on the morphology of the antennular accessory branch: the "Short Accessory Branch clade" or "Hippolysmata Clade", the "Long Accessory Branch clade" or "Lysmata Clade" and the "Unguiform Branch clade". Lysmata moorei (Rathbun, 1901) and L. galapagensis Schmitt, 1924 are two closely related species occurring on the eastern and western sides of the Panama Isthmus, respectively. The two species are considered sister taxa, included in the monophyletic "Long Branch Clade" (Fiedler et al. 2010).

The present paper describes the zoeal characters of two trans-isthmian, closely related species, Lysmata moorei (Rathbun, 1901) and L. galapagensis Schmitt 1924, using laboratory cultured material. The characters are compared with the larval features of $L$. seticaudata, the only species in the "Long Branch Clade" whose larvae have been described previously (Calado et al. 2004), and with the larval genus Eretmocaris (Bate 1888), considering the striking similarity of $L$. galapagensis larvae and E. corniger from the tropical eastern Pacific.

\section{Materials and methods}

Larval culture techniques

Two ovigerous L. galapagensis collected on the Pacific coast of Nicaragua and imported to the United States of America were purchased directly from the commercial importer; further details on the site of collection are unknown. Three ovigerous $L$. moorei were collected under a rocky ledge in a tide pool at $2 \mathrm{~m}$ depth at Salvador, Bahia, Brazil. Newly hatched larvae were mass-cultured according to the methods described by Calado et al. (2003b). The Nicaragua material was reared in the United States and the Brazilian material in Brazil. For each species, the larvae were haphazardly sampled every day from the culture tanks in order to determine their zoeal stage. Whenever possible, at least ten individuals were sampled for each species (exceptions: L. galapagensis fifth and seventh zoeae; L. moorei first, second and third zoeae). The sampled larvae were fixed in $4 \%$ formaldehyde for later morphological analysis.

Larval drawings and measurements

Drawings and measurements were made with the aid of a camera lucida on a binocular Wild M8 and on a Zeiss 
microscope. The preparation of slides was temporary. Larval descriptions followed the method proposed by Clark et al. (1998). Setal terminology corresponds to Garm (2004), while aesthetascs are classified according to Gurney (1937). Whenever necessary, aesthetascs were drawn truncated to facilitate the illustration of the antennule. Similarly, the long plumose setae on maxilliped exopods and on pleopod exopods were also drawn truncated, and setules from setae were omitted whenever necessary. The exopods of pereiopods were also cut to facilitate preparation.

The following measurements were taken as follows: total length (TL) - measured from tip of rostrum to posterior end of telson; carapace length (CL) - measured from tip of rostrum to posterior margin of carapace; and rostrum length (RL) - measured from tip of rostrum to eye socket (except in zoea I where it was measured from tip of rostrum to an imaginary line crossing the orbital margin).

Identification of taxa sampled was confirmed with comparison of $16 \mathrm{~S}$ mtDNA sequence data for spent females cataloged in GenBank; L. moorei (HQ315578) and L. galapagensis (HQ315577). Both larval series have been deposited in the Instituto Nacional de Recursos Biológicos-IPIMAR in Lisbon, Portugal (IPIMAR/H/Ll/11/2006 and IPIMAR/H/Lb/11/2007).

\section{Results}

Under laboratory conditions, larvae of L. galapagensis and L. moorei hatch as common caridean zoeae. Due to laboratory constraints, it was not possible to obtain the complete larval series for both species.

Concerning $L$. galapagensis, the larval series from zoea I to zoea VII were obtained, while the final zoeal and the decapodid stages were lacking. The first and the seventh zoeal stages are described in detail; for the second to fifth stages, only differences to previous ones are mentioned.

For L. moorei, zoeae I-IV and the last zoeal stage were obtained. The first and the last zoeal stages are described in detail, and as in L. galapagensis, for the second to fourth zoeae only differences to previous stages are assigned.

Lysmata galapagensis Schmitt, 1924 (Figs. 1, 2, 3, 4, 5, 6).

First zoea (Fig. 1)

Dimension: $\quad \mathrm{TL}=2.46-2.89 \mathrm{~mm} ; \mathrm{CL}=0.92-1.00 \mathrm{~mm}$.

Carapace (Fig. 1A): rostrum slender and pointed, longer than the antennular peduncle, eyes compound and sessile; 1 pterigostomial spine and 4 denticles along anterior ventral margin.

Antennule (Fig. 1B): peduncle unsegmented, terminally with 1 long plumose seta and a small process; short outer

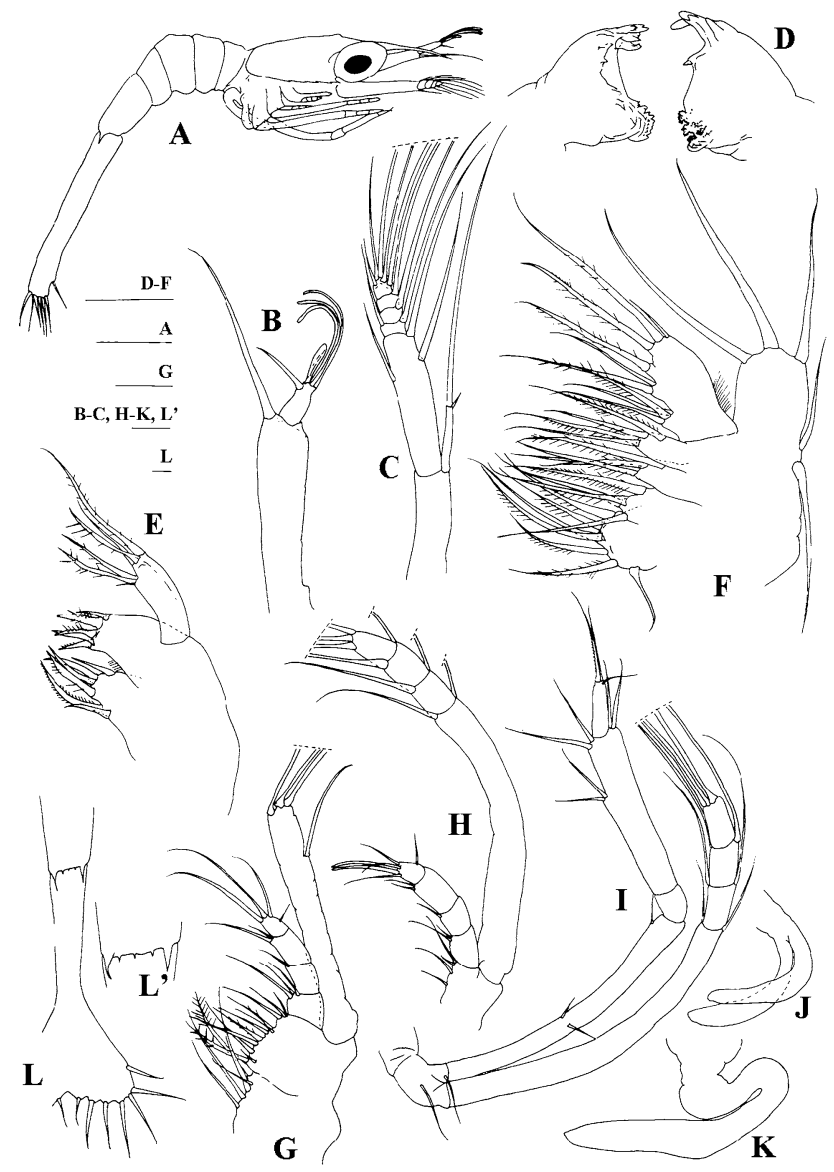

Fig. 1 Lysmata galapagensis. First zoea: A total animal, lateral view; $\mathbf{B}$ antennule; $\mathbf{C}$ antenna; D mandibles; $\mathbf{E}$ maxillule; $\mathbf{F}$ maxilla; $\mathbf{G}$ first maxilliped; H second maxilliped; I third maxilliped; J first pereiopod; $\mathbf{K}$ fifth pereiopod; $\mathbf{L}$ fifth pleomere and telson; $\mathbf{L}^{\prime}$, detail of the fifth pleomere. Scale bars: $0.5 \mathrm{~mm}(\mathbf{A}) ; 0.1 \mathrm{~mm}\left(\mathbf{B}-\mathbf{L}^{\prime}\right)$

flagellum with 1 plumose seta, 3 long aesthetascs and 1 short and stout aesthetasc that ends in a spoon-shaped membrane with thickened midrib on distal margin.

Antenna (Fig. 1C): protopod unsegmented; endopod apically with 1 long plumose seta and 1 short spine; scaphocerite 5-segmented, 4 short segments distally, with 9 plumose setae on inner margin, 2 plumose setae on outer margin, and a simple small seta on apex.

Mandibles (Fig. 1D): slightly asymmetrical, palp absent, armature of incisor and molar processes as illustrated.

Maxillule (Fig. 1E): coxal endite with 2 serrulate, 2 papposerrate and 2 simple setae, basial endite with 3 cuspidate and 2 simple setae; endopod with 2 strong subterminal and 3 strong terminal papposerrate setae.

Maxilla (Fig. 1F): coxal endite bilobed with 7-8+4 serrulate and papposerrate setae, basial endite bilobed with 3-4+4 papposerrate setae; endopod unsegmented bearing 


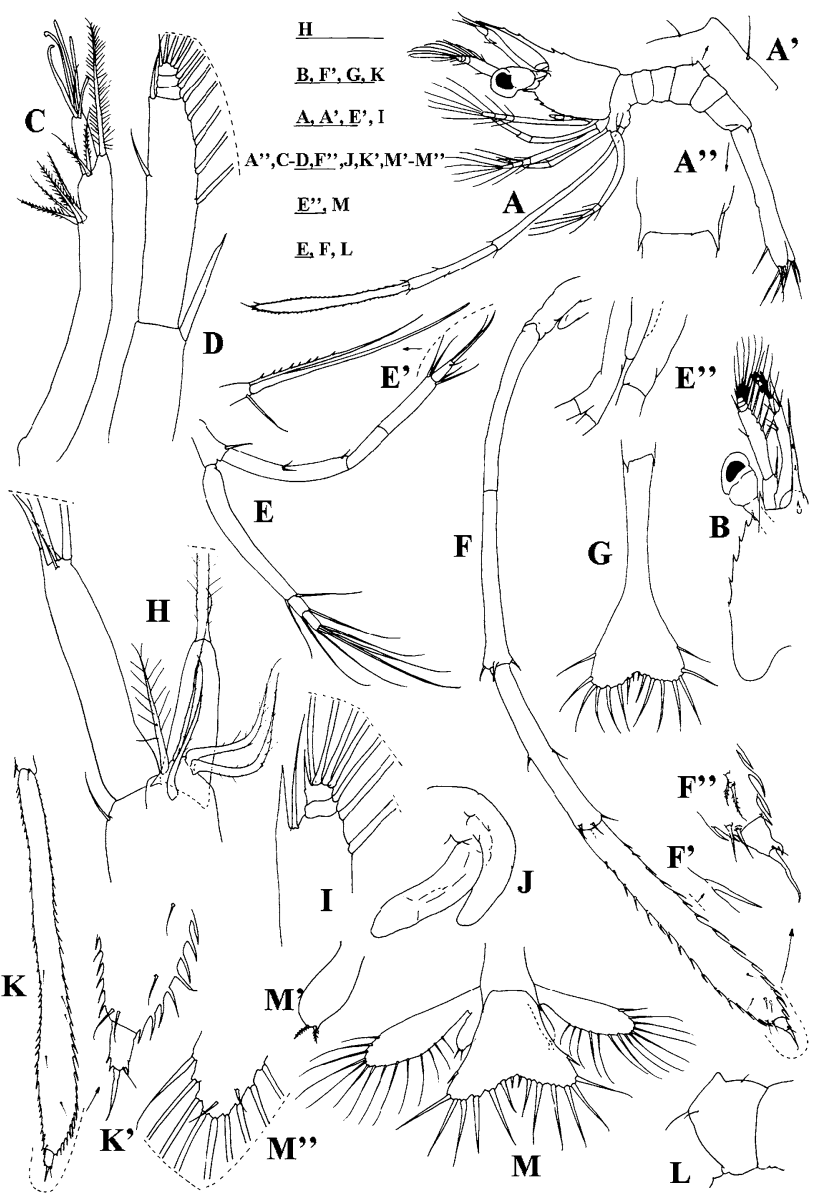

Fig. 2 Lysmata galapagensis. Second zoea: A total animal, lateral view; $\mathbf{A}^{\prime}$ detail of third pleomere, lateral view; $\mathbf{A}^{\prime \prime}$ detail of fifth pleomere, dorsal view; $\mathbf{B}$ carapace, dorsal view; $\mathbf{C}$ antennule; $\mathbf{D}$ antenna; $\mathbf{E}$ first pereiopod; $\mathbf{E}^{\prime}$ detail of first pereiopod dactylus setae; $\mathbf{E}^{\prime \prime}$ detail of basis of pereiopods; $\mathbf{F}$ fifth pereiopod; $\mathbf{F}^{\prime}$ detail of fifth pereiopod propodus lateral spine; $\mathbf{F}^{\prime \prime}$ detail of fifth pereiopod end of propodus and dactylus; $\mathbf{G}$ fifth pleomere and telson. Third zoea: $\mathbf{H}$ detail of antennule flagella; I detail of scaphocerite distal segments; $\mathbf{J}$ second pereiopod; $\mathbf{K}$ fifth pereiopod; $\mathbf{K}^{\prime}$ detail of fifth pereiopod propodus and dactylus; $\mathbf{L}$ detail of third pleomere, lateral view; $\mathbf{M}$ telson and uropods; $\mathbf{M}^{\prime}$, endopod of uropods; $\mathbf{M}^{\prime \prime}$, exopod of uropods. Scale bars: $0.5 \mathrm{~mm}(\mathbf{A}, \mathbf{B}, \mathbf{G}, \mathbf{K}) ; 0.1 \mathrm{~mm}\left(\mathbf{A}^{\prime}-\mathbf{A}^{\prime \prime}, \mathbf{C}-\mathbf{F}^{\prime \prime}, \mathbf{H}-\mathbf{J}, \mathbf{K}^{\prime}-\mathbf{M}^{\prime \prime}\right)$

$3+2+1+3$ papposerrate and simple setae; scaphognathite with 5 marginal plumose setae.

First maxilliped (Fig. 1G): coxa with 4-5 papposerrate setae; basis with 10-12 papposerrate setae; endopod 4-segmented with $3,1,2,3$ papposerrate and 1 simple setae; exopod unsegmented, bearing subapically 1 shorter seta on lateral margin and 3 long plumose setae terminally.

Second maxilliped (Fig. $1 \mathrm{H}$ ): basis with $1+1+2$ papposerrate setae; endopod 4-segmented with 3, 1, 2, 5 papposerrate and 1 simple setae terminally; exopod 4 -segmented, bearing 2, 2, 2, 3 plumose setae.

Third maxilliped (Fig. 1I): basis with 2-3 papposerrate setae; endopod 4-segmented, with $2+1,0,2+4,2$ papposerrate

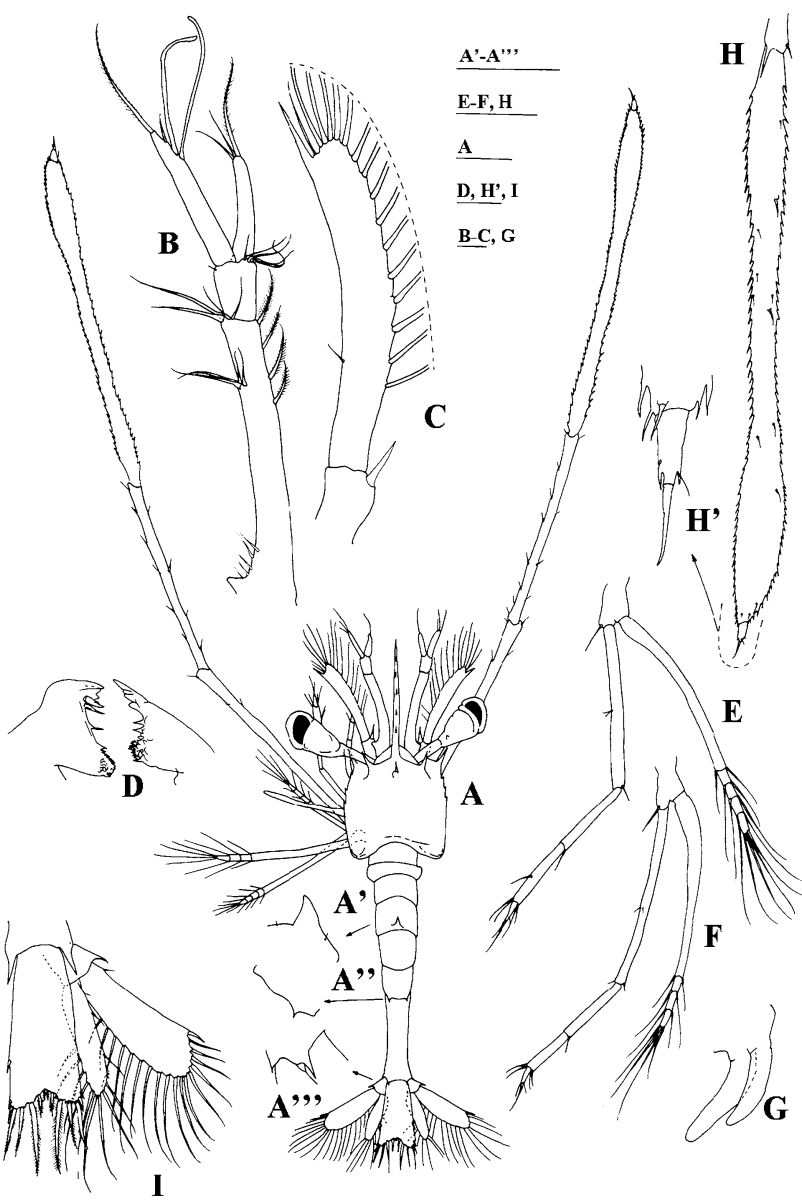

Fig. 3 Lysmata galapagensis. Fourth zoea: A total animal, dorsal view; $\mathbf{A}^{\prime}$ third pleomere, lateral view of procurved spine; $\mathbf{A}^{\prime \prime}$ fifth pleomere, lateral view of dorso-lateral spines; $\mathbf{A}^{\prime \prime \prime}$ sixth pleomere, lateral view of dorsal- and ventral-lateral spines; $\mathbf{B}$ antennule; $\mathbf{C}$ antenna; D mandibles; E first pereiopod; $\mathbf{F}$ second pereiopod; $\mathbf{G}$ third pereiopod; $\mathbf{H}$ fifth pereiopod, end of propodus and dactylus; $\mathbf{H}^{\prime}$ detail of fifth pereiopod end of propodus and dactylus; $\mathbf{I}$ telson and uropods. Scale bars: $0.5 \mathrm{~mm}\left(\mathbf{A}-\mathbf{A}^{\prime \prime \prime}, \mathbf{D}-\mathbf{F}, \mathbf{H}, \mathbf{I}\right) ; 0.1 \mathrm{~mm}\left(\mathbf{B}-\mathbf{C}, \mathbf{G}, \mathbf{H}^{\prime}\right)$

and 1 simple setae; exopod 4-segmented, bearing 2, 2, 2, 3 plumose setae.

First pereiopod (Fig. 1J): biramous bud.

Second to fourth pereiopods: absent.

Fifth pereiopod (Fig. 1K): uniramous bud.

Pleon (Fig. 1A, L, L'): 5 pleomeres; 2 dorso-lateral spines and 3-4 very small dorsal spines on posterior margin of the 5th pleomere.

Pleopods: absent.

Uropods: absent.

Telson (Fig. 1L): triangular, broader posteriorly; indented medially with $7+7$ setae (inner 5 plumose, outer 2 plumose on proximal axis only); minute spines between and around setae. 


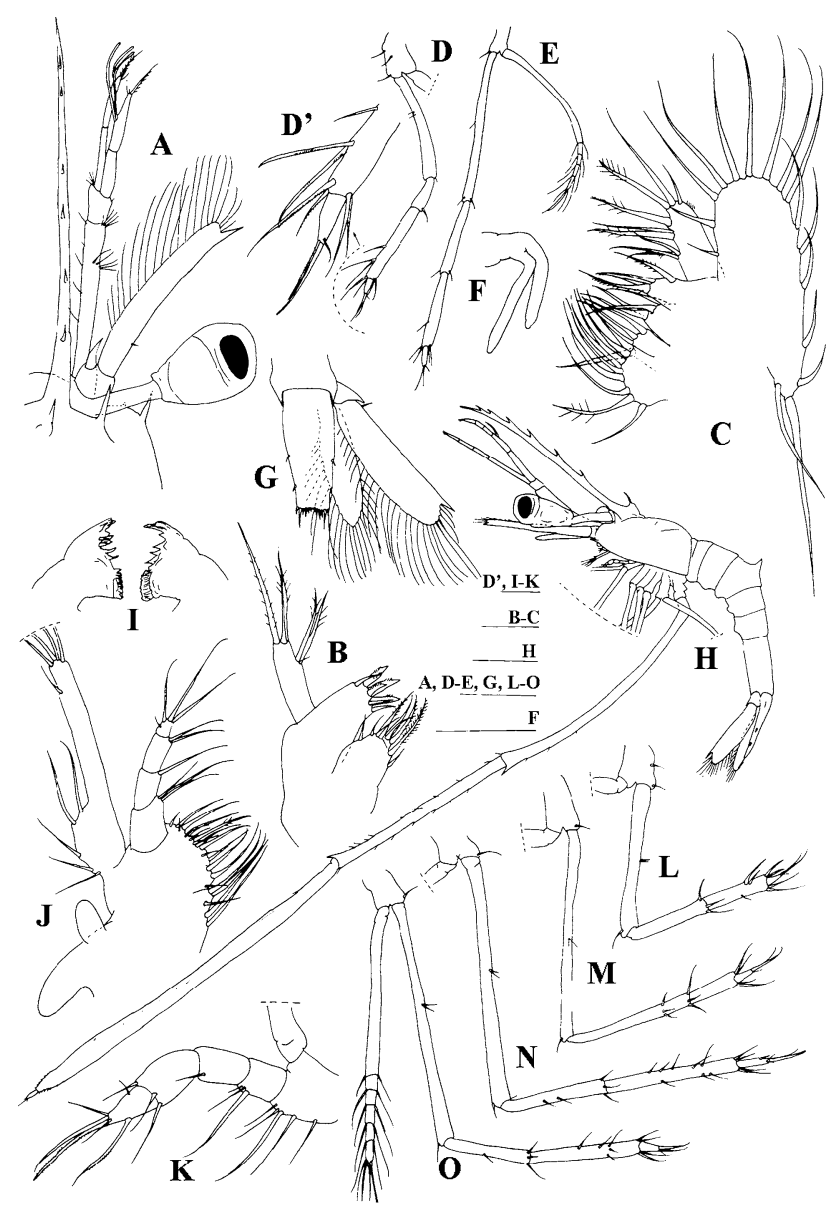

Fig. 4 Lysmata galapagensis. Fifth zoea: A carapace, dorsal view; B maxillule; C maxilla; D third maxilliped; $\mathbf{D}^{\prime}$ third maxilliped, detail of propodus and dactylus; $\mathbf{E}$ third pereiopod; $\mathbf{F}$ fourth pereiopod; $\mathbf{G}$ telson and uropods. Sixth zoea: H total animal, lateral view; $\mathbf{I}$ mandibles; $\mathbf{J}$ first maxilliped; $\mathbf{K}$ second maxilliped; $\mathbf{L}$ first pereiopod; $\mathbf{M}$ second pereiopod; $\mathbf{N}$ third pereiopod; $\mathbf{O}$ fourth pereiopod. Scale bars: $1 \mathrm{~mm}(\mathbf{H}) ; 0.5 \mathrm{~mm}(\mathbf{A}, \mathbf{D}, \mathbf{E}-\mathbf{G}, \mathbf{L}-\mathbf{O}) ; 0.1 \mathrm{~mm}\left(\mathbf{B}-\mathbf{C}, \mathbf{D}^{\prime}\right.$, I-K)

Second zoea (Fig. 2A-G)

Dimension: $\quad \mathrm{TL}=2.81-3.34 \mathrm{~mm} ; \mathrm{CL}=0.89-1.19 \mathrm{~mm}$.

Carapace (Fig. 2A, B): eyes stalked, with peduncle shorter than antennal peduncle; rostrum long and slender, almost as long as carapace, with 2-3 dorsal teeth and 1 postrostral spine; with 1 pair of supraorbital, 1 pair of antennal, and 1 pair of pterigostomial spines followed by 4-5 denticles on anterior ventral margin.

Antennule (Fig. 2B, C): peduncle unsegmented, bearing subdistally 3-4 short and distally 2 short +1 long plumose setae; outer flagellum with 4 long +1 short spoon-shaped membranous aesthetascs and 1 simple seta.

Antenna (Fig. 2B, D): protopod unsegmented; endopod small, pointed, conical shaped; scaphocerite 4-segmented, 3 short segments distally, with 11-12 plumose setae on inner

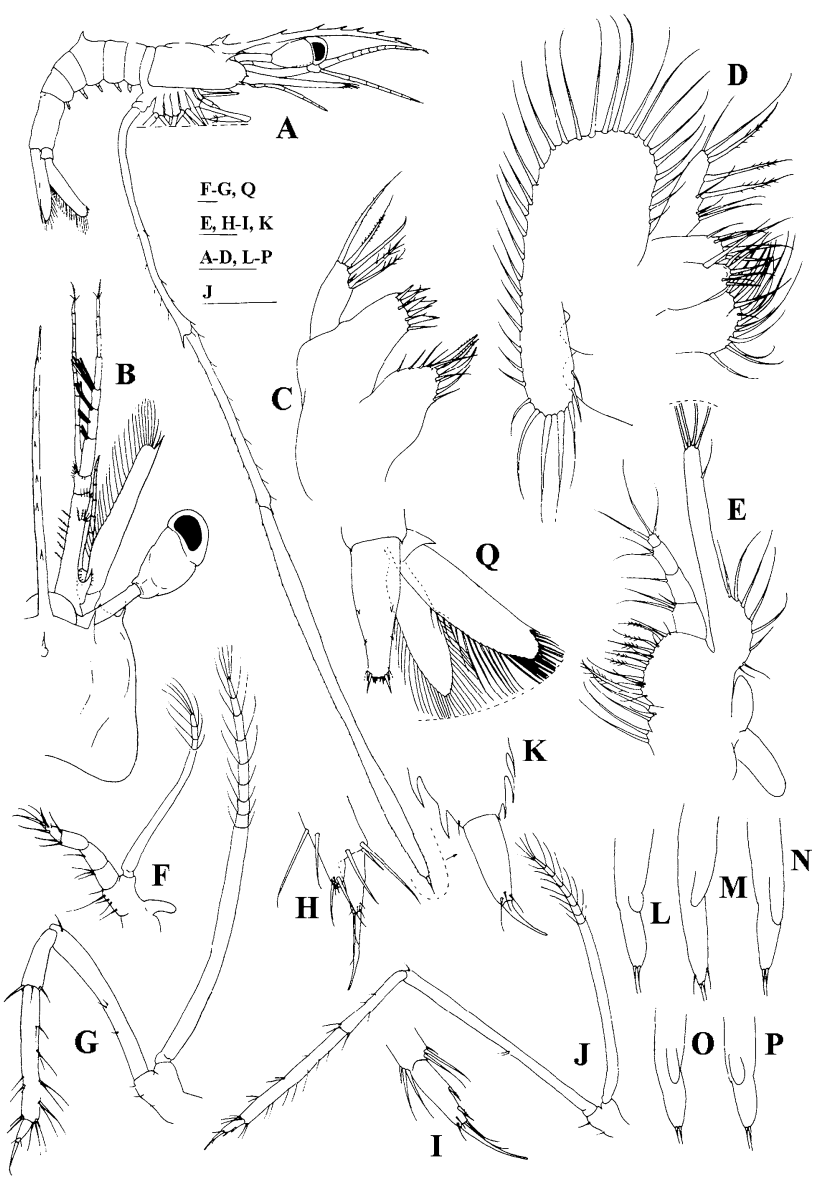

Fig. 5 Lysmata galapagensis. Seventh zoea: A total animal, lateral view; B carapace, dorsal view; C maxillule; D maxilla; $\mathbf{E}$ first maxilliped; $\mathbf{F}$ second maxilliped; $\mathbf{G}$ third maxilliped; $\mathbf{H}$ first pereiopod; I third pereiopod; $\mathbf{J}$ fourth pereiopod; $\mathbf{K}$ fifth pereiopod, propodus and dactylus; L first pleopod; $\mathbf{M}$ second pleopod; $\mathbf{N}$ third pleopod; $\mathbf{O}$ fourth pleopod; $\mathbf{P}$ fifth pleopod; $\mathbf{Q}$ telson and uropods. Scale bars: $1 \mathrm{~mm}(\mathbf{A}) ; 0.5 \mathrm{~mm}(\mathbf{B}, \mathbf{J}) ; 0.1 \mathrm{~mm}(\mathbf{C}-\mathbf{I}, \mathbf{K}-\mathbf{Q})$

margin, 2 plumose setae on outer margin and 1 simple small seta on apex.

Mandibles: unchanged.

Maxillule: coxal endite with 6-7 serrulate, papposerrate and simple setae; basial endite with 6-7 strong cuspidate and simple setae; endopod with 2 papposerrate and 1 short simple subterminal setae and 3 strong terminal papposerrate setae.

Maxilla: coxal endite bilobed with 7-9+4 serrulate and papposerrate setae; scaphognathite with 8 marginal plumose setae. Otherwise unchanged.

First maxilliped: coxa with 5 papposerrate setae; exopod with 1 subapical shorter seta on lateral margin and 4 long plumose setae terminally. Otherwise unchanged.

Second maxilliped: basis with $1+1+2-3$ papposerrate setae; exopod 4-segmented, bearing 2, 2, 2, 4 plumose setae. Otherwise unchanged. 


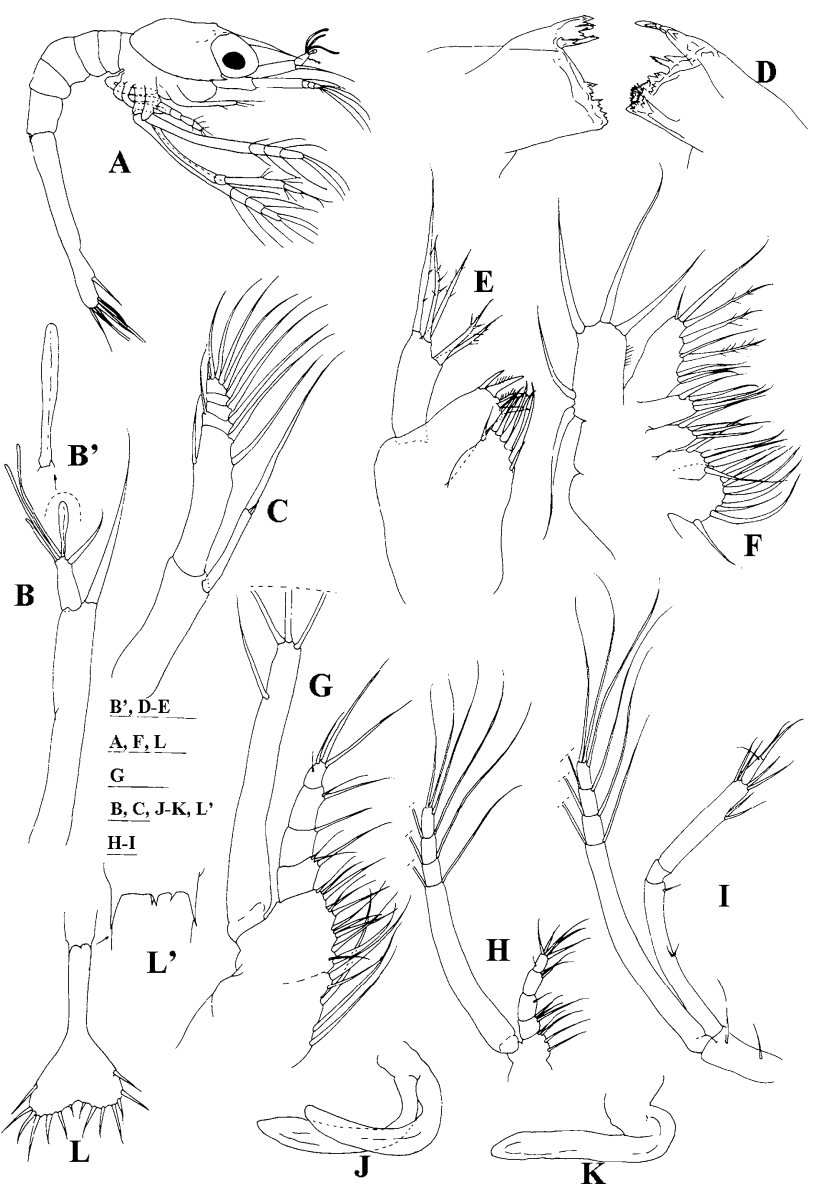

Fig. 6 Lysmata moorei. First zoea: A total animal, lateral view; $\mathbf{B}$ antennule; $\mathbf{B}^{\prime}$ antennule, detail of short aesthetasc; $\mathbf{C}$ antenna; D mandibles; E maxillule; F maxilla; $\mathbf{G}$ first maxilliped; $\mathbf{H}$ second maxilliped; I third maxilliped; $\mathbf{J}$ first pereiopod; $\mathbf{K}$ fifth pereiopod; $\mathbf{L}$ fifth pleomere and telson; $\mathbf{L}^{\prime}$, detail of the fifth pleomere. Scale bars: $0.5 \mathrm{~mm}(\mathbf{A}, \mathbf{L}) ; 0.1 \mathrm{~mm}\left(\mathbf{B}-\mathbf{K}, \mathbf{L}^{\prime}\right)$

Third maxilliped: basis with 3 papposerrate setae; exopod 4-segmented, bearing 2, 2, 2, 4 plumose setae. Otherwise unchanged.

First pereiopod (Fig. 2E, E'): functional; biramous; basis with 1 simple seta; endopod 4-segmented, with $2+1,0,4,2$ papposerrate and 1 simple setae; exopod 3 -segmented with 2, 2, 4 plumose setae.

Second pereiopod (Fig. 2E", F): present as a very small biramous bud.

Third and fourth pereiopods: absent.

Fifth pereiopod (Fig. 2F, $\mathrm{F}^{\prime}, \mathrm{F}^{\prime \prime}$ ): functional; uniramous; almost as long as the total larva; basis with 1 simple seta; ischium naked; merus with one spinous process and 2 strong simple setae terminally; carpus with 2 simple +4 simple terminal setae; propodus measuring approximately one-third of whole pereiopod, flattened, and paddle-like enlarged with margins serrated (17-20 and 19-22 spines on each margin), 2-4 small pappose setae along the surface, and bearing 2 strong simple setae distally; dactylus small with 1 strong spine, 1 simple subterminal and 1 strong simple terminal setae.

Pleon (Fig. 2A, A', A"): third pleomere dorsally with a small protuberance and 2 pairs of simple setae; fifth pleomere with 2 dorso-lateral spines and $0-2$ very small dorsal spines on the posterior margin.

Pleopods: absent.

Uropods: absent.

Telson (Fig. 2G): $8+8$ plumose setae, the outer 2 plumose on proximal axis only.

Third zoea (Fig. 2H-M")

Dimension: $\quad \mathrm{TL}=3.50-3.77 \mathrm{~mm} ; \mathrm{CL}=1.29-1.56 \mathrm{~mm}$.

Carapace: ocular peduncle as long as antennal peduncle, rostrum as long as carapace, with 3-4 dorsal teeth and 1 postrostral spine; with 1 pair of supraorbital, 1 pair of antennal, and 1 pair of pterigostomial spines followed by 3-4 denticles on ventral margin.

Antennule (Fig. 2H): peduncle 2-segmented; first segment with 2 small plumose setae proximally, 2-3 small plumose setae positioned at four-fifths of the length of the segment, and 5 small plumose setae distally; distal segment with 5-6 plumose +1 simple setae; inner flagellum with 1 short plumose seta; outer flagellum with 1 small simple +1 long plumose setae +2 long aesthetascs.

Antenna (Fig. 2I): scaphocerite 3-segmented; proximal segment with 8 plumose setae on inner margin, 1 small simple seta proximally and 1 strong spine followed by a plumose seta distally; second segment with 1 plumose seta on inner margin; distal segment with 4 long plumose setae and 1 strong spine on apex. Otherwise unchanged.

Mandibles: unchanged besides size.

Maxillule: coxal endite with 7-8 serrulate, papposerrate and simple setae; basial endite with 7 strong cuspidate and simple setae. Otherwise unchanged.

Maxilla: coxal endite bilobed with $8-9+4$ serrulate and papposerrate setae; scaphognathite with 8-9 marginal plumose setae. Otherwise unchanged.

First maxilliped: coxa with 5 papposerrate setae; basis with 11-12 papposerrate setae. Otherwise unchanged.

Second maxilliped: basis with $1+1+3$ papposerrate setae. Otherwise unchanged. 
Third maxilliped: basis with 2 papposerrate setae. Otherwise unchanged.

First pereiopod: endopod 4-segmented, with 2+1, 1, 4, 2 papposerrate and 1 simple setae; exopod 4-segmented with 2, 2, 2, 4 plumose setae.

Second pereiopod (Fig. 2J): present as a biramous bud.

Third and fourth pereiopods: absent.

Fifth pereiopod (Fig. $2 \mathrm{~K}, \mathrm{~K}^{\prime}$ ): longer than the whole larva; basis without any seta; ischium with 0-2 simple setae; merus with 3-4 simple setae and one spinous process +2 strong simple setae terminally; carpus with 14-17 simple setae; propodus measuring one-third of whole pereiopod, flattened and paddle-like enlarged with margins serrated (34-43 and 36-47 spines on each margin), 5-8 small pappose setae along the surface, and 2 simple setae distally; dactylus small with 2-3 strong spines, 1 simple subterminal and 1 strong simple terminal setae.

Pleon (Fig. 2L): third pleomere dorsally with a small anteriorly curved spine and 2 pairs of simple setae; fifth pleomere with 2 dorso-lateral spines; sixth pleomere separated from telson, with one pair of dorso-lateral spines.

Pleopods: absent.

Uropods (Fig. 2M, M', M"): biramous; endopod small with 2 short plumose setae apically; exopod well developed reaching the end of telson, with 13-14 marginal plumose setae and 2 plumose setae on dorsal margin.

Telson (Fig. 2M): separated from the sixth pleomere, with one pair of lateral spines followed by $7+7$ plumose setae.

\section{Fourth zoea (Fig. 3)}

Dimension: $\quad \mathrm{TL}=4.14-4.63 \mathrm{~mm} ; \mathrm{CL}=1.61-2.15 \mathrm{~mm}$.

Carapace (Fig. 3A): eye with two-thirds of antennal length, rostrum one and a half times longer than carapace, with 5-6 dorsal teeth and 1 postrostral spine; with 1 pair of supraorbital, 1 pair of antennal, and 1 pair of pterigostomial spines followed by 3-4 denticles on ventral margin.

Antennule (Fig. 3A, B): peduncle 2-segmented; first segment with 4 plumose setae distributed along inner margin, 5-7 small plumose setae on stylocerite, 4-5 small plumose setae positioned at four-fifths of the length of the segment, and 4-5 small plumose setae distally; distal segment with 4-6 plumose +1 simple setae; inner flagellum with 1 plumose +2 simple setae; outer flagellum with 2 subterminal aesthetascs, and 1 small simple +1 long plumose setae terminally.
Antenna (Fig. 3A, C): endopod short and triangular shaped; scaphocerite unsegmented; inner margin with 1617 plumose setae; 1 small simple seta proximally on outer margin; a very strong spine on apex.

Mandibles (Fig. 3D): incisor and molar processes as illustrated.

Maxillule: unchanged besides size.

Maxilla: scaphognathite with 12 marginal plumose setae. Otherwise unchanged.

First maxilliped: basis with 12 papposerrate setae. Otherwise unchanged.

Second maxilliped: unchanged besides size.

Third maxilliped: exopod 5-segmented, bearing 2, 2, 2, 2, 4 plumose setae. Otherwise unchanged.

First pereiopod (Fig. 3E): endopod 4-segmented, with $2+1,1,1+4,2$ papposerrate and 1 simple setae; exopod 5-segmented with 2, 2, 2, 2, 4 plumose setae.

Second pereiopod (Fig. 3F): functional; biramous; basis with 1 simple seta; endopod 4-segmented, with 2+2, $0-1$, 4, 2 papposerrate and 1 simple setae; exopod 4-segmented with 2, 2, 2, 4 plumose setae.

Third pereiopod (Fig. 3G): present as a very small biramous bud.

Fourth pereiopod: absent.

Fifth pereiopod $\left(\mathrm{Fig} .3 \mathrm{H}, \mathrm{H}^{\prime}\right)$ : one and a half times longer than the whole larva; basis with 0-1 simple seta; ischium with 1-2 simple setae; merus with 6-10 simple setae and one spinous process; carpus with 18-22 simple setae and one spinous process; propodus measuring two-fifths of the whole pereiopod, flattened and paddle-like enlarged with margins serrated (52-59 and 53-59 spines on each margin), 11-14 small pappose setae along the surface, and 2 strong simple setae distally; dactylus small with 2-3 strong spines, 1 simple subterminal and 1 strong simple terminal setae.

Pleon (Fig. 3A, A', A", $\mathrm{A}^{\prime \prime \prime}$ ): third pleomere dorsally with an anteriorly curved spine and 2 pairs of simple setae; fifth pleomere with 2 dorso-lateral spines; sixth pleomere separated from telson, with one pair of dorso-lateral spines and one pair of small ventral-lateral spines.

Pleopods: absent.

Uropods (Fig. 3A, I): protopod without setae, with a spine; endopod with 1-2 short plumose setae proximally on outer margin and 10-12 plumose setae along distal and inner margins; exopod as long as telson, with 1 short plumose seta proximally on outer margin, 1 spine on apex followed by 
16-18 marginal plumose setae along distal and inner margins, and 2-3 short plumose setae on dorsal margin.

Telson (Fig. 3A, I): almost rectangular shaped, with one pair of lateral spines, 1 pair of outer spines and 6 pairs of plumose setae on the posterior end.

Fifth zoea (Fig. 4 A-G)

Dimension: $\quad \mathrm{TL}=6.08-6.40 \mathrm{~mm} ; \mathrm{CL}=2.88-3.12 \mathrm{~mm}$.

Carapace (Fig. 4A): rostrum now measuring twice over the carapace, with 6 dorsal teeth, 1 postrostral spine; with 1 pair of supraorbital, 1 pair of antennal, and 1 pair of pterigostomial spines. No denticles on ventral margin.

Antennule (Fig. 4A): peduncle 2-segmented; first segment with 4-5 plumose setae distributed along inner margin, 6 small plumose setae on stylocerite, 5 small plumose setae positioned at two-thirds the length of the segment, and 5 small plumose setae distally; distal segment with 5 plumose +1 simple setae. Inner flagellum 2-segmented, proximal segment naked, distal segment with 2 small simple +1 plumose setae. Outer flagellum 2-segmented, proximal segment naked, distal segment with 3 subterminal aesthetascs +2 small simple and 1 plumose terminal setae.

Antenna (Fig. 4A): inner margin with 20-22 plumose setae; 1 small simple seta proximally on outer margin; a very strong spine on apex.

Mandibles: unchanged besides size.

Maxillule (Fig. 4B): coxal endite with 8-9 serrulate, papposerrate and simple setae; basial endite with 8 strong cuspidate and simple setae. Otherwise unchanged.

Maxilla (Fig. 4C): coxal endite bilobed with 9+4 serrulate and papposerrate setae; scaphognathite with 16-19 marginal plumose setae. Otherwise unchanged.

First maxilliped: basis with 12-13 papposerrate setae; epipod bud present. Otherwise unchanged.

Second maxilliped: unchanged besides size.

Third maxilliped (Fig. 4D, D'): basis with 3 papposerrate setae; endopod 4-segmented, with $2+1,1,1+2+4,2$ papposerrate and 1 simple setae; exopod 7 -segmented, bearing 2 , 2, 2, 2, 2, 2, 4 plumose setae. Otherwise unchanged.

First pereiopod: exopod 7-segmented, each segment with 2 and the last one with 4 plumose setae. Otherwise unchanged.

Second pereiopod: exopod 7-segmented, each segment with 2 and the last one with 4 plumose setae. Otherwise unchanged.
Third pereiopod (Fig. 4E): functional; biramous; basis with 1 simple seta; endopod 4-segmented, with 1+2, 2, 1+4, 2 papposerrate and 1 simple setae; exopod 5-segmented with 2, 2, 2, 2, 4 plumose setae.

Fourth pereiopod (Fig. 4F): present as a biramous bud.

Fifth pereiopod: five-thirds longer than the whole larva; carpus with 22-23 simple setae and one spinous process; propodus flattened and paddle-like enlarged with margins serrated (54-56 and 56-67 spines on each margin), 10-14 small pappose and 3-4 short strong plumose setae along the surface, and 2 strong simple setae distally; dactylus small with 3 strong spines, 1 simple subterminal and 1 strong simple terminal setae. Otherwise unchanged.

Pleon: anteriorly curved spine in the third pleomere increased in size; fifth pleomere now without spines; sixth pleomere with one pair of dorso-lateral spines and one pair of small ventral-lateral spines.

Pleopods: absent.

Uropods (Fig. 4G): endopod longer than telson, endopod with 3 short plumose setae proximally on outer margin and 20-22 plumose setae along distal and inner margins; exopod with 5 short plumose setae proximally on outer margin, 1 spine on apex followed by 24-26 marginal plumose setae along distal and inner margins, and 4-6 short plumose setae on dorsal margin.

Telson (Fig. 4G): margins laterally parallel, slightly narrower posteriorly, with two pairs of lateral spines, and 6 pairs of short plumose setae on the posterior end.

Sixth zoea (Fig. 4H-O)

Dimension: $\quad \mathrm{TL}=6.64-7.68 \mathrm{~mm} ; \mathrm{CL}=3.28-4.00 \mathrm{~mm}$

Carapace (Fig. 4H): eyes still with two-thirds of antennal length, presence of one pair of cervical carinae, rostrum measuring twice over the carapace with 6--8 dorsal teeth, 1 postrostral spine; with 1 pair of supraorbital, 1 pair of antennal, and 1 pair of pterigostomial spines.

Antennule: peduncle 2-segmented, first segment with 6-7 plumose setae distributed along inner margin, 7-9 small plumose setae on stylocerite, 5-6 small plumose setae positioned at two-thirds of the length of the segment, and 4-5 small plumose setae distally; distal segment with 5-6 plumose +1 simple setae. Inner flagellum 4-segmented, proximal segment with 1-2 small simple setae, second segment with 1-2 small simple setae, third segment with 1-3 small simple setae, and distal segment with 3-4 short simple +1 plumose setae. Outer flagellum 5-segmented, proximal segment with 0-1 seta, second segment with 1-2 short simple setae and 3 aesthetascs, third segment with 0-1 simple seta 
and 4 aesthetascs, fourth segment with 2-3 short simple setae, and distal segment with 3 short simple +1 plumose setae.

Antenna: endopod reaching half the length of antennal scale, 2-segmented, proximal segment naked, distal segment with 3 short simple setae terminally; inner margin with 24-25 plumose setae. Otherwise unchanged.

Mandibles (Fig. 4I): unchanged besides size.

Maxillule: coxal endite with 9-10 serrulate, papposerrate and simple setae; basial endite with 9 strong cuspidate and simple setae. Otherwise unchanged.

Maxilla: coxal endite bilobed with $8-9+4$ serrulate and papposerrate setae; scaphognathite with 26-28 marginal plumose setae. Otherwise unchanged.

First maxilliped (Fig. 4J): coxal endite with 4-5 papposerrate setae; basial endite with 14-15 papposerrate setae; exopod unsegmented with 3-5 plumose setae on proximal lobe, 1 short subterminal +4 long plumose setae on distal margin. Otherwise unchanged.

Second maxilliped (Fig. 4K): basis with 1+1+2-3 papposerrate setae; endopod 4-segmented with 3, 1, 3, 5 papposerrate and 1 simple setae terminally. Otherwise unchanged.

Third maxilliped: basis with 3 papposerrate setae; endopod 4-segmented, with $2+1,2,7+4,2$ papposerrate and 1 simple setae; exopod 7-segmented, 1st segment with $1+2$, 2 nd to 7 th segments with 2 and the last one with 4 plumose setae. Otherwise unchanged.

First pereiopod (Fig. 4L): endopod 4-segmented, with $2+1,3,3-4+4,2$ papposerrate and 1 simple setae; exopod 9-segmented, each with 2 and the last one with 4 plumose setae. Otherwise unchanged.

Second pereiopod (Fig. 4M): endopod 4-segmented, with $2+2,3+3,4,2$ papposerrate and 1 simple setae; exopod 9-segmented, each with 2 and the last one with 4 plumose setae. Otherwise unchanged.

Third pereiopod (Fig. 4N): endopod 4-segmented, with $2+2,5,8-10+4,3$ papposerrate and 2 simple setae; exopod 8 -segmented, each with 2 and the last one with 4 plumose setae. Otherwise unchanged.

Fourth pereiopod (Fig. 4O): functional; biramous; basis with 1 simple seta; endopod 4-segmented, with $2+1,1+3$, $5-6+4,2$ papposerrate and 1 simple setae; exopod 6-segmented, each with 2 and the last one with 4 plumose setae.

Fifth pereiopod (Fig. 4H): five-thirds longer than the whole larva; merus with 10-12 simple setae and one spinous process; carpus with 21-27 simple setae and one spinous process; propodus length remains as two-fifths of the whole pereiopod, flattened and paddle-like enlarged with margins serrated (56-62 and 58-73 spines on each margin), 7-10 small pappose setae along the surface, and 2 strong simple setae distally; dactylus small with 2-3 strong spines, 2 simple subterminal and 1 strong simple terminal setae. Otherwise unchanged.

Pleon (Fig. 4H): anteriorly curved spine in the third pleomere increased in size. Otherwise unchanged.

Pleopods (Fig. 4H): presence of small protuberances in pleomeres.

Uropods: endopod with 3 short plumose setae proximally on outer margin and 24-27 plumose setae along distal and inner margins; exopod with 3-5 short plumose setae proximally on outer margin, 1 spine on apex followed by 29-31 marginal plumose setae along distal and inner margins, and 5-6 short plumose setae on dorsal margin.

Telson: narrowing toward the posterior end, with one pair of lateral spines followed by 1 pair of outer spines and 6 pairs of short setae of which the inner 4 pairs are plumose and the outer 2 pairs are simple.

\section{Seventh zoea (Fig. 5)}

Dimension: $\quad \mathrm{TL}=8.24-8.48 \mathrm{~mm}$; $\mathrm{CL}=4.08-4.32 \mathrm{~mm}$.

Carapace (Fig. 5A, B): rostrum measuring more than twice over the carapace with 7 dorsal teeth; otherwise unchanged besides size.

Antennule (Fig. 5B): peduncle 2-segmented, first segment with 6 plumose setae distributed along inner margin, 9 small plumose setae on stylocerite, 6 small plumose setae at twothirds of the length of the segment, and 6 small plumose setae distally; distal segment with 5 plumose +2 simple setae. Inner flagellum 8-segmented, proximal and second segments with 4 small simple setae each, third segment with 3 simple +1 plumose short setae, fourth and fifth segments with 3 and 4 small simple setae, respectively, sixth segment with 4 simple +1 plumose short setae, seventh segment with 4 short simple setae, and distal segment with 2 short +2 longer simple +1 plumose setae. Outer flagellum 8 -segmented, proximal segment with 2 simple setae and 3 aesthetascs, second segment with 3 aesthetascs in a middle position +3 short simple setae and 3 aesthetascs terminally, third segment with 3 simple setae and 4 aesthetascs, fourth to sixth segments with 4, 5, and 3 short simple setae, respectively, and distal segment with 3 short simple +1 plumose setae.

Antenna (Fig. 5B): flagellum 8-segmented, shorter than scaphocerite, with 2 smaller segments proximally, 3rd segment the longer one followed by 5 short segments distally, all bearing 3-5 simple setae; scaphocerite now with 28 plumose setae. 
Mandibles: enlarged in size.

Maxillule (Fig. 5C): coxal endite with 9-11 serrulate, papposerrate and simple setae; basial endite with 10-11 strong cuspidate and simple setae. Otherwise unchanged.

Maxilla (Fig. 5D): coxal endite bilobed with 10-11+4 serrulate and papposerrate setae; basial endite with $7+6$ papposerrate setae; scaphognathite with 36 marginal plumose setae. Otherwise unchanged.

First maxilliped (Fig. 5E): coxal endite with 5 papposerrate setae; basial endite with 15-17 papposerrate setae; exopod unsegmented with 7-9 plumose setae on proximal lobe, 1 short subterminal +4 long plumose setae on distal margin; epipod bilobed. Otherwise unchanged.

Second maxilliped (Fig. 5F): basis with $1+1+3$ papposerrate setae; epipod bud present. Otherwise unchanged.

Third maxilliped (Fig. 5G): endopod 4-segmented, with 4, 3, 15-16, 2 papposerrate and 2 simple setae; exopod 9-segmented, each segment with 2 and the last one with 4 plumose setae. Otherwise unchanged.

First pereiopod (Fig. 5H): endopod subchelate, with internal distal margin of propodus produced forward to about one-third of dactylus, 4-segmented, with $2+1,1+3,13,7$ papposerrate and simple setae; exopod 10-segmented, each segment with 2 and the last one with 4 plumose setae. Otherwise unchanged.

Second pereiopod: endopod 4-segmented, with 4, 7, 5, 5 papposerrate and simple setae; exopod 10-segmented, each segment with 2 and the last one with 4 plumose setae. Otherwise unchanged.

Third pereiopod (Fig. 5I): endopod 4-segmented, with 5, 5, 21, 6 papposerrate and simple setae; exopod 10-segmented, each segment with 2 and the last one with 4 plumose setae. Otherwise unchanged.

Fourth pereiopod (Fig. 5J): basis with 2 simple seta; endopod 4-segmented, with $2+1,6,18,5$ papposerrate and simple setae; exopod 8-segmented, each segment with 2 and the last one with 4 plumose setae.

Fifth pereiopod (Fig. 5K): propodus flattened and paddlelike enlarged with margins serrated (60 and 80 spines on each margin), 7 small pappose setae along the surface, and 7 simple setae distally; dactylus small with 3 simple subterminal and 1 strong simple terminal setae. Otherwise unchanged.

Pleon (Fig. 5A): anteriorly curved spine in the third pleomere increased in size. Otherwise unchanged.

Pleopods (Fig. 5L-P): endopod rudimentary, bud-like; exopod with 2-4 apical simple setae.

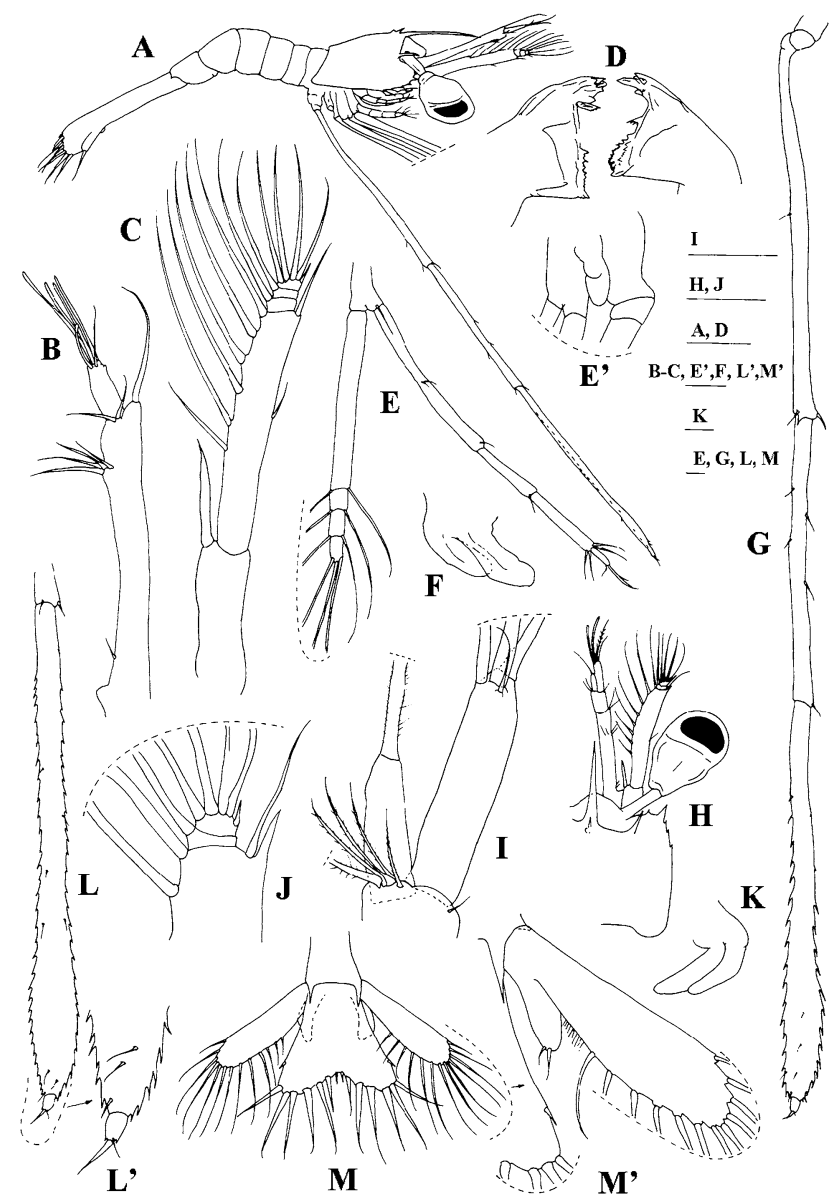

Fig. 7 Lysmata moorei. Second zoea: A total animal, lateral view; $\mathbf{B}$ antennule; $\mathbf{C}$ antenna; D mandibles; $\mathbf{E}$ first pereiopod; $\mathbf{E}^{\prime}$ detail of basis of pereiopods; F second pereiopod; $\mathbf{G}$ fifth pereiopod. Third zoea: $\mathbf{H}$ carapace, dorsal view; $\mathbf{I}$ detail of antennule flagella; $\mathbf{J}$ detail of scaphocerite distal segments; K second pereiopod; $\mathbf{L}$ fifth pereiopod; $\mathbf{L}^{\prime}$ detail of fifth pereiopod propodus and dactylus; $\mathbf{M}$ telson and uropods; $\mathbf{M}^{\prime}$ detail of endopod and exopod of uropods. Scale bars: $0.5 \mathrm{~mm}$ $(\mathbf{A}, \mathbf{H}) ; 0.1 \mathrm{~mm}\left(\mathbf{B}-\mathbf{G}, \mathbf{I}-\mathbf{M}^{\prime}\right)$

Uropods (Fig. 5Q): endopod with 6 short plumose setae proximally on outer margin and 32 plumose setae along distal and inner margins; exopod with 4 short plumose setae proximally on outer margin, 1 spine on apex followed by 33 marginal plumose setae along distal and inner margins, and 5 short plumose setae on dorsal margin.

Telson (Fig. 5Q): narrowing toward the posterior end, bears one pair of lateral spines followed by 1 pair of plumose setae and 6 pairs of strong short setae.

Lysmata moorei (Rathbun, 1901) (Figs. 6, 7, 8, 9).

First zoea (Fig. 6)

Dimension: $\quad \mathrm{TL}=2.77-2.81 \mathrm{~mm} ; \mathrm{CL}=0.92-0.96 \mathrm{~mm}$. 


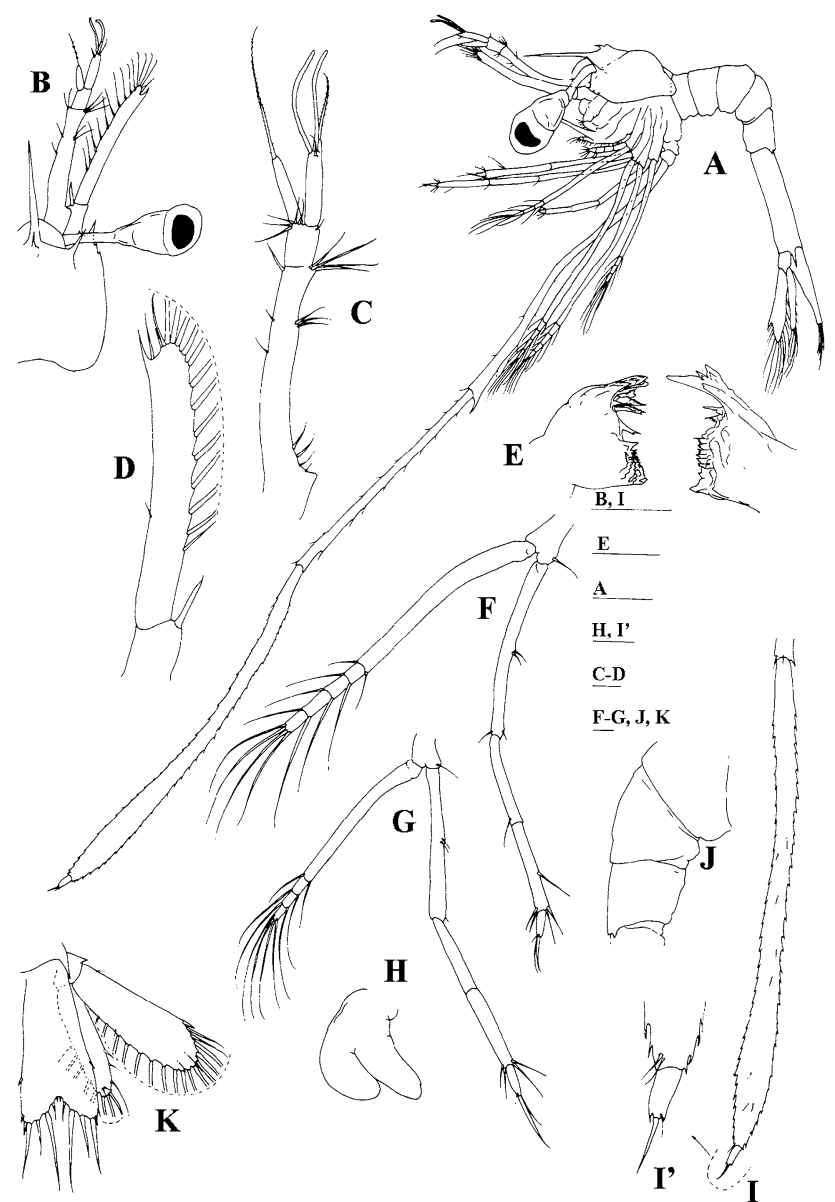

Fig. 8 Lysmata moorei. Fourth zoea: A total animal, lateral view; $\mathbf{B}$ carapace, dorsal view; $\mathbf{C}$ antennule; $\mathbf{D}$ antenna; $\mathbf{E}$ mandibles; $\mathbf{F}$ first pereiopod; G second pereiopod; $\mathbf{H}$ third pereiopod; I fifth pereiopod, propodus and dactylus; I' $\mathbf{I}^{\prime}$ detail of fifth pereiopod propodus and dactylus; J pleon, lateral view; $\mathbf{K}$ telson and uropods. Scale bars: $0.5 \mathrm{~mm}$ $(\mathbf{A}-\mathbf{B}, \mathbf{I}) ; 0.1 \mathrm{~mm}\left(\mathbf{C}-\mathbf{H}, \mathbf{I}^{\prime}-\mathbf{J}\right)$

Carapace (Fig. 6A): rostrum slender and pointed, longer than the antennular peduncle, eyes compound and sessile; 1 pterigostomial spine and 4-5 denticles along anterior ventral margin.

Antennule (Fig. 6B, B'): peduncle unsegmented, with 1 long plumose seta and a small process terminally; short outer flagellum with 1 plumose seta, 3 long aesthetascs and 1 short and stout aesthetasc that ends in a spoon-shaped membrane with thickened midrib at distal margin.

Antenna (Fig. 6C): protopod unsegmented; endopod apically with 1 long plumose seta and 1 short spine; scaphocerite 5-segmented, 4 short segments distally, with 9 plumose setae on inner margin, 2 plumose setae on outer margin, and a simple small seta on apex.

Mandibles (Fig. 6D): asymmetrical, palp absent, armature of incisor and molar processes as illustrated.

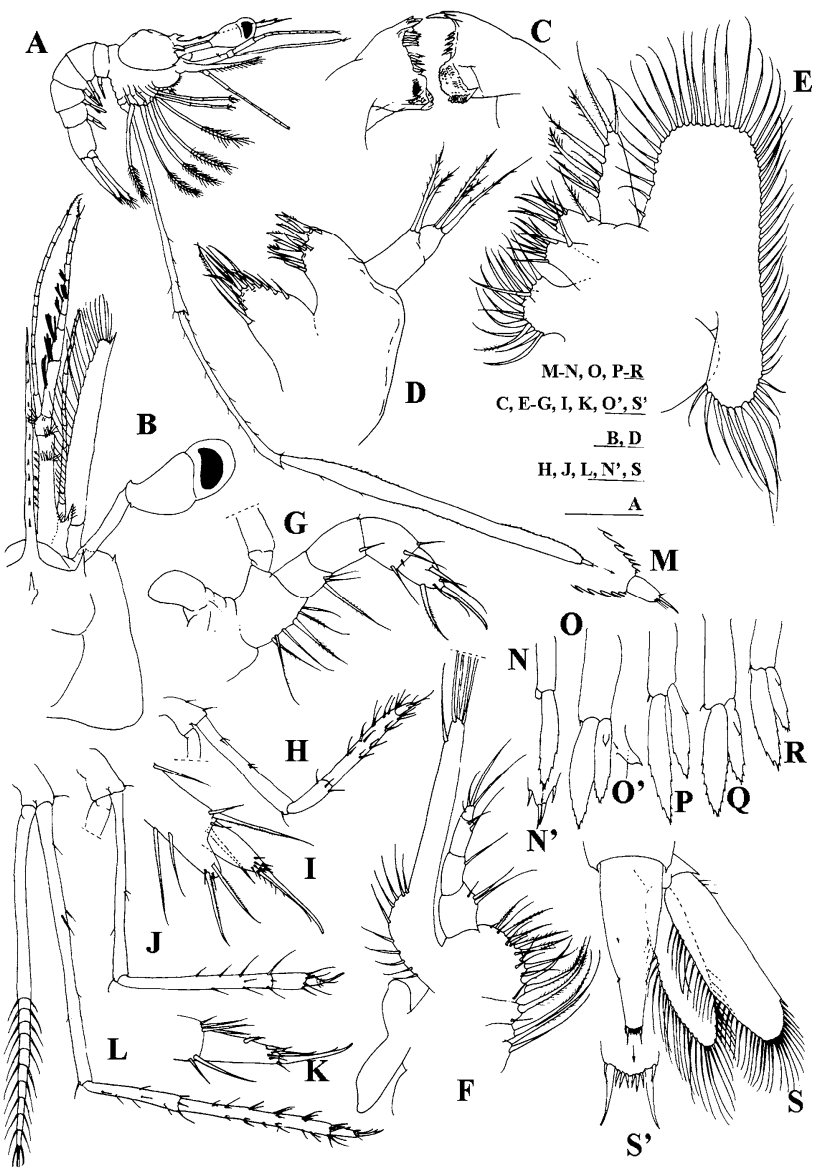

Fig. 9 Lysmata moorei. Last zoea: A total animal, lateral view; $\mathbf{B}$ carapace, dorsal view; C mandibles; D maxillule; $\mathbf{E}$ maxilla; $\mathbf{F}$ first maxilliped; $\mathbf{G}$ second maxilliped; $\mathbf{H}$ third maxilliped, propodus and dactylus; I first pereiopod, propodus and dactylus; J second pereiopod; $\mathbf{K}$ third pereiopod, propodus and dactylus; $\mathbf{L}$ fourth pereiopod; $\mathbf{M}$ fifth pereiopod, propodus and dactylus; $\mathbf{N}$ first pleopod; $\mathbf{N}^{\prime}$ first pleopods, detail of spines; $\mathbf{O}$ second pleopod; $\mathbf{O}^{\prime}$ second pleopod, detail of appendix interna; $\mathbf{P}$ third pleopod; $\mathbf{Q}$ fourth pleopod; $\mathbf{R}$ fifth pleopod; $\mathbf{S}$ telson and uropods. Scale bars: $1 \mathrm{~mm}(\mathbf{A}) ; 0.5 \mathrm{~mm}(\mathbf{B}, \mathbf{H}, \mathbf{J}, \mathbf{L}, \mathbf{S})$; $0.1 \mathrm{~mm}(\mathbf{C}-\mathbf{G}, \mathbf{I}, \mathbf{K}, \mathbf{M}-\mathbf{R})$

Maxillule (Fig. 6E): coxal endite with 2 serrulate, 3 papposerrate and 2 simple setae, basial endite with 3 cuspidate and 2 simple setae; endopod with 2 strong subterminal and 3 strong terminal papposerrate setae.

Maxilla (Fig. 6F): coxal endite bilobed with $8+4$ serrulate and papposerrate setae, basial endite bilobed with $4+4$ papposerrate setae; endopod unsegmented bearing $3+2+1+3$ papposerrate and simple setae; scaphognathite with 5 marginal plumose setae.

First maxilliped (Fig. 6G): coxa with 5 papposerrate setae; basis with 12 papposerrate setae; endopod 4-segmented with 3, 1, 2, 3 papposerrate and 1 simple setae; exopod unsegmented, bearing subapically 1 shorter seta on lateral margin and 3 long plumose setae terminally. 
Second maxilliped (Fig. 6H): basis with $1+1+2-3$ papposerrate setae; endopod 4-segmented with 3, 1, 2, 5 papposerrate and 1 simple setae terminally; exopod 4-segmented, bearing 2, 2, 2, 3 plumose setae.

Third maxilliped (Fig. 6I): basis with 2 papposerrate setae; endopod 4-segmented, with $2+1,0,2+4,2$ papposerrate and 1 simple setae; exopod 4-segmented, bearing 2, 2, 2, 3 plumose setae.

First pereiopod (Fig. 6J): biramous bud.

Second to fourth pereiopods: absent.

Fifth pereiopod (Fig. 6K): uniramous bud.

Pleon (Fig. 6L, L'): 5 pleomeres; 2 dorso-lateral spines and 3-4 very small dorsal spines on posterior margin of the 5th pleomere.

Pleopods: absent.

Uropods: absent.

Telson (Fig. 6L): triangular, broader posteriorly; indented medially with $7+7$ setae (inner 5 plumose, outer 2 plumose on proximal axis only); minute spines between and around setae.

\section{Second zoea (Fig. 7A-G')}

Dimension: $\quad \mathrm{TL}=3.08-3.23 \mathrm{~mm} ; \mathrm{CL}=1.00-1.04 \mathrm{~mm}$.

Carapace (Fig. 7A): eyes stalked, with peduncle longer than antennal peduncle; rostrum long and slender, as long as carapace, with 2-3 dorsal teeth and 1 postrostral spine; with 1 pair of supraorbital, 1 pair of antennal, and 1 pair of pterigostomial spines followed by 3-4 denticles on anterior ventral margin.

Antennule (Fig. 7B): peduncle unsegmented bearing proximally 1 short, followed by $4-5$ short, and 2 short +1 long plumose setae distally; outer flagellum with 1 very small subterminal spine, 1 short simple seta, and 1 short +4 long aesthetascs.

Antenna (Fig. 7C): protopod unsegmented; endopod small pointed conical shaped; scaphocerite 4-segmented, 3 short segments distally, with 12 plumose setae on inner margin, 2 plumose setae on outer margin and 1 simple small seta on apex.

Mandibles (Fig. 7D): unchanged.

Maxillule: basial endite with 6-7 strong cuspidate and simple setae. Otherwise unchanged.

Maxilla: scaphognathite with 8 marginal plumose setae. Otherwise unchanged.

First maxilliped: exopod with 1 subapical shorter seta on lateral margin and 4 long plumose setae terminally. Otherwise unchanged.
Second maxilliped: exopod 4-segmented, bearing 2, 2, 2, 4 plumose setae. Otherwise unchanged.

Third maxilliped: exopod 4-segmented, bearing 2, 2, 2, 4 plumose setae. Otherwise unchanged.

First pereiopod (Fig. 7E): functional; biramous; basis with 1 simple seta; endopod 4-segmented, with 2+1, 1, 4, 2 papposerrate and 1 simple setae; exopod 3 -segmented with 2, 2, 3 plumose setae.

Second pereiopod (Fig. 7E', F): present as a very small biramous bud.

Third and fourth pereiopods: absent.

Fifth pereiopod (Fig. 7G): functional; uniramous; longer than the whole larva; basis without seta; ischium with $0-1$ seta; merus with one spinous process and 1-3 simple setae; carpus with 7 simple setae; propodus measuring approximately one-third of whole pereiopod, flattened and paddlelike enlarged with margins serrated (14-16 and 16-19 spines on each margin), and 5-6 small pappose setae along the surface; dactylus small with 1 simple subterminal and 1 strong simple terminal setae.

Pleon (Fig. 7A): fifth pleomere with 2 dorso-lateral spines and 1-2 very small dorsal spines on the posterior margin.

Pleopods: absent.

Uropods: absent.

Telson (Fig. 7A): $8+8$ plumose setae, the outer ones plumose on proximal axis only.

Third zoea (Fig. 7H-M')

Dimension: $\quad \mathrm{TL}=3.23-3.44 \mathrm{~mm} ; \mathrm{CL}=1.02-1.24 \mathrm{~mm}$.

Carapace (Fig. 7H): eyes with two-thirds of antennal length; rostrum a little shorter than carapace. Otherwise unchanged.

Antennule (Fig. 7H, I): peduncle 2-segmented; first segment with 2 small plumose setae proximally, 2-3 small plumose setae positioned at one-fourth of the length of the segment, and 4-5 small plumose setae distally; distal segment with 5-6 plumose +1 simple setae; inner flagellum with 1 short plumose seta; outer flagellum with 1 small simple +1 long plumose setae +2 long aesthetascs.

Antenna (Fig. 7H, J): scaphocerite 3-segmented; proximal segment with 8 plumose setae on inner margin, 1 small simple seta proximally and 1 strong spine followed by a plumose seta distally; second segment with 1 plumose seta on inner margin; distal segment with 4 long plumose setae and 1 strong spine on apex. Otherwise unchanged. 
Mandibles: unchanged besides size.

Maxillule: endopod with 2 papposerrate and 1 short simple subterminal setae and 3 strong terminal papposerrate setae. Otherwise unchanged.

Maxilla: unchanged besides size.

First maxilliped: unchanged besides size.

Second maxilliped: unchanged besides size.

Third maxilliped: endopod 4-segmented, with 2+1, 1, 2+4, 2 papposerrate and 1 simple setae. Otherwise unchanged.

First pereiopod: exopod 4-segmented with 2, 2, 2, 4 plumose setae. Otherwise unchanged.

Second pereiopod (Fig. 7K): present as a biramous bud.

Third and fourth pereiopods: absent.

Fifth pereiopod (Fig. 7L, L'): three halves longer than the whole larva; merus with 4-5 simple setae and one spinous process; carpus with 10-13 simple setae; propodus measuring approximately two-fifths of whole pereiopod, flattened and paddle-like enlarged with margins serrated (24-29 and 26-30 spines on each margin), 6-8 small pappose setae along the surface; dactylus small with 2 strong spines, 1 simple subterminal and 1 strong simple terminal setae.

Pleon: third pleomere with one pair of dorsal simple setae; fifth pleomere with 2 small dorso-lateral spines; sixth pleomere separated from telson, with one pair of dorso-lateral spines and one pair of small ventral-lateral spines.

Pleopods: absent.

Uropods (Fig. 7M, $\mathrm{M}^{\prime}$ ): biramous; endopod small with 2 short plumose setae apically; exopod well developed reaching the end of telson, with 12-13 marginal plumose setae and 2 plumose setae on dorsal margin.

Telson (Fig. 7M): separated of the sixth pleomere, with one pair of lateral spines and $7+7$ plumose setae.

Fourth zoea (Fig. 8)

Dimension: $\quad \mathrm{TL}=3.44-3.66 \mathrm{~mm} ; \mathrm{CL}=1.13-1.29 \mathrm{~mm}$.

Carapace (Fig. 8A, B): eyes with two-thirds of antennal length, presence of one pair of cervical carinae, rostrum as long as the carapace, pair of pterigostomial spines, followed by 2-3 denticles on ventral margin. Otherwise unchanged.

Antennule (Fig. 8A, C): peduncle 2-segmented; first segment with 4 plumose setae distributed along inner margin, 4-5 small plumose setae on stylocerite, 2-3 small plumose setae positioned at four-fifths of the length of the segment, and 3-4 small plumose setae distally; distal segment with 5-6 plumose +1 simple setae; inner flagellum with 1 plumose seta; outer flagellum with 2 subterminal aesthetascs, and 1 small simple +1 long plumose setae terminally.

Antenna (Fig. 8A, D): scaphocerite unsegmented, with 14 plumose setae on inner margin, followed by 1 very small simple, 1 short plumose setae, and a very strong spine on apex.

Mandibles (Fig. 8E): incisor and molar processes as illustrated.

Maxillule: coxal endite with 7-8 serrulate, papposerrate and simple setae, basial endite with 7-8 cuspidate and simple setae. Otherwise unchanged.

Maxilla: coxal endite bilobed with $8-9+4$ serrulate and papposerrate setae; scaphognathite with 9-10 marginal plumose setae. Otherwise unchanged.

First maxilliped: unchanged besides size.

Second maxilliped: unchanged besides size.

Third maxilliped: exopod 5-segmented, bearing 2, 2, 2, 2, 4 plumose setae. Otherwise unchanged.

First pereiopod (Fig. 8F): endopod 4-segmented, with $2+2,1,1+4,2$ papposerrate and 1 simple setae; exopod 5-segmented with 2, 2, 2, 2, 4 plumose setae.

Second pereiopod (Fig. 8G): functional; biramous; basis with 1 simple seta; endopod 4-segmented, with 2+1, 0, 4, 2 papposerrate and 1 simple setae; exopod 4-segmented with 2, 2, 2, 4 plumose setae.

Third pereiopod (Fig. 8H): present as a very small biramous bud.

Fourth pereiopod: absent.

Fifth pereiopod (Fig. 8I, $\mathrm{I}^{\prime}$ ): two times longer than the whole larva; merus with 8-10 simple setae and one spinous process; carpus with 20-28 simple setae and one spinous process; propodus length is one-third of the whole pereiopod, flattened and paddle-like enlarged with margins serrated (31-38 and 32-39 spines on each margin), 11-14 small pappose setae along the surface, and 2 strong simple setae distally. Otherwise unchanged.

Pleon (Fig. 8A, J): unchanged besides size.

Pleopods: absent.

Uropods (Fig. 8A, K): protopod without setae, with a spine; endopod with 8-9 plumose setae along distal and inner margins and 4-5 short plumose setae on dorsal margin; 
exopod longer than telson, with 1 spine on apex followed by $15-16$ marginal plumose setae along distal and inner margins, and 3 short plumose setae on dorsal margin.

Telson (Fig. 8A, K): almost rectangular shaped, with one pair of lateral spines followed by 2 pairs of outer spines and 5 pairs of plumose setae on the posterior end.

\section{Last zoea (Fig. 9)}

Dimension: $\quad \mathrm{TL}=7.81-9.35 \mathrm{~mm} ; \mathrm{CL}=3.85-4.84 \mathrm{~mm}$.

Carapace (Fig. 9A, B): eyes with four-fifths of antennal length; presence of one pair of cervical carinae; rostrum measuring almost twice over the carapace, with 7-9 dorsal teeth, 1 postrostral spine; with 1 pair of supraorbital, 1 pair of antennal, and 1 pair of pterigostomial spines.

Antennule (Fig. 9B): peduncle 2-segmented, proximal segment with 6-7 plumose setae distributed along inner margin, 8-11 small plumose setae on stylocerite, 6-9 small plumose setae positioned at four-fifths of the length of the segment, and 5-7 plumose +1 simple small setae distally; distal segment with 5-6 plumose $+3-4$ simple small setae. Inner flagellum 12-segmented, proximal to eleventh segments with 2--6 small simple setae, and distal segment with 4-5 short simple +1 plumose setae. Outer flagellum 10-segmented, proximal segment with 5 aesthetascs, second and third segments with 4 aesthetascs each, fourth segment with 2-4 simple setae and 5 aesthetascs, fifth segment with 3-4 short simple setae and 2 aesthetascs, sixth to ninth segments with 2-4 short simple setae, and distal segment with 3 short simple +2 plumose setae.

Antenna (Fig. 9B): flagellum long and slender, with 10segments bearing 2-5 short simple setae each; scaphocerite now with 30-32 plumose setae. Otherwise unchanged.

Mandibles (Fig. 9C): armature of incisor and molar processes as illustrated.

Maxillule (Fig. 9D): coxal endite with 13-16 serrulate, papposerrate and simple setae; basial endite with 12-14 strong cuspidate and simple setae. Otherwise unchanged.

Maxilla (Fig. 9E): coxal endite bilobed with 11-13+4 serrulate and papposerrate setae; basial endite with 8-10+7-10 papposerrate setae; scaphognathite with 4751 marginal plumose setae. Otherwise unchanged.

First maxilliped (Fig. 9F): coxal endite with 5 papposerrate setae; basial endite with 17-19 papposerrate setae; exopod unsegmented with 6-10 plumose setae on proximal lobe, 1 short subterminal +4 long plumose setae on distal margin; epipod bilobed. Otherwise unchanged.
Second maxilliped (Fig. 9G): basis with $3+1+2$ papposerrate setae; endopod 4-segmented with 3, 2, 4, 5-6 papposerrate and simple setae terminally. Otherwise unchanged.

Third maxilliped (Fig. 9H): endopod 4-segmented, with $4-5,3,19-22,5$ papposerrate and simple setae; exopod 10segmented, each segment with 2 and the last one with 4 plumose setae. Otherwise unchanged.

First pereiopod (Fig. 9I): endopod subchelate, with internal distal margin of propodus produced forward to about a half of dactylus; 4-segmented, with 4-5, 4-5, 12-14, 11-13 papposerrate and simple setae; exopod 11-segmented, 1st segment with $1+2$, 2nd to 10th segments with 2 and the last one with 4 plumose setae. Otherwise unchanged.

Second pereiopod (Fig. 9J): endopod 4-segmented, with 4-5, 9-14, 5-9, 7-12 papposerrate and simple setae; exopod 11-segmented, 1st segment with $1+2$, 2nd to 10th segments with 2 and the last one with 4 plumose setae. Otherwise unchanged.

Third pereiopod (Fig. 9K): endopod 4-segmented, with 6-8, 7-10, 21-24, 7-10 papposerrate and simple setae; exopod 10segmented, 1st segment with $1+2$, 2nd to 9th segments with 2 and the last one with 4 plumose setae. Otherwise unchanged.

Fourth pereiopod (Fig. 9L): endopod 4-segmented, with 6-7, 7-10, 26-29, 7-8 papposerrate and simple setae; exopod 11-segmented, each segment with 2 and the last one with 4 plumose setae.

Fifth pereiopod (Fig. 9M): two times longer than the whole larva; merus with 11-15 simple setae and one spinous process; carpus with 37-41 simple setae and one spinous process; propodus length is two-fifths of the whole pereiopod, flattened and paddle-like enlarged with margins serrated (78-90 and 81-95 spines on each margin), and 1115 small pappose setae along the surface; dactylus small with 3-4 simple subterminal and 1 strong simple terminal setae. Otherwise unchanged.

Pleon (Fig. 9A): sixth pleomere with one pair of dorsolateral spines and one pair of small ventral-lateral spines.

Pleopods (Fig. 9N-R): protopod with 0-1 short simple seta; first pleopod endopod naked and exopod with 9-12 small spines; second to fifth pleopods endopods with 6-12, $6-12,8-12,7-9$, and 6 small spines, respectively; second to fifth pleopods exopods with $12-16,15-19,13-16$, and 10-14 small spines, respectively; small appendix interna present from second to fifth pleopods, with a spinous termination.

Uropods (Fig. 9S): endopod with 4-5 short plumose setae proximally on outer margin and 37-42 plumose setae along distal and inner margins; exopod with 3-4 short plumose 
setae proximally on outer margin, 1 spine on apex followed by 36-43 marginal plumose setae along distal and inner margins, and 3-4 short plumose setae on dorsal margin.

Telson (Fig. 9S, $S^{\prime}$ ): rather triangular, narrower distally than proximally, bears one pair of dorso-lateral spines followed by 1 pair of lateral spines and 5 pairs of strong short setae.

\section{Discussion}

Morphological comparisons of larval stages

Beyond the first zoeal stage, the general morphological features displayed by L. galapagensis and L. moorei larvae are those considered to be diagnostic of the genus Lysmata: eyes stalked with a long peduncle; 5th pereiopod developing before pereiopods 2-4 and exhibiting an enlarged, flattened, and paddle-like propodus with serrated margins. The first zoeal stage of both species is similar to that of $L$. seticaudata, as at hatching the first and fifth pereiopods are biand uniramous buds, respectively (Calado et al. 2004, p. 739, Fig. 1a, 1j-k). A comparison of the most specific larval features of the first, fourth, seventh, and last zoeal stages of L. galapagensis and L. moorei with those of L. seticaudata is presented in Table 1 .

The studied species develop very steadily. Although the larval series are incomplete, we may expect that both species will have a maximum number of nine zoeal stages as is known for L. seticaudata. Both L. galapagensis and L. moorei hatch with the first and fifth pereiopods as buds, which become functional in the second zoeal stage. In the third zoeal stage, all the three species have the second pereiopods as biramous buds that become functional in the fourth zoeal stage, while the fourth pereiopods are present as biramous buds. The seventh zoea of L. galapagensis presents more advanced characters than the same stage of L. seticaudata: the antennal flagellum as long as scaphocerite with eight segments, biramous pleopods with endopods as buds and exopods with apical setae, and the telson narrower at the posterior end, typical of a penultimate stage (Calado et al. 2004, p. 746, Fig. 6a-k). This suggests that L. galapagensis will need just one more stage to complete the zoeal development. Accordingly, L. moorei may also complete the zoeal development with eight or nine stages: their larvae hatch with the first and fifth pereiopods as buds, and in the fourth zoeal stage all morphological structures are at the same level of development as in the other two species (Table 1). When summarizing the larval characters of the genus Lysmata, Gurney (1937) predicted that it should display nine zoeal stages. This is confirmed by our results for L. galapagensis and L. moorei, as it has also been found previously for L. seticaudata (Calado et al. 2004). The most striking difference between the zoeal developmental series of L. seticaudata and L. galapagensis refers to the pleopods, which take four stages to complete in the former species and probably only three stages in the latter species. Knowlton and Alavi (1995) stated that the most evident differences in the larval series of Lysmata were the appearance and development of pereiopods and pleopods.

The knowledge of larval Lysmata will certainly be valuable for the study of phylogenetic relationships. On the basis of the available data, at least two developmental patterns of Lysmata species can be distinguished. The first one is represented by L. galapagensis, L. moorei, and L. seticaudata: larvae hatch with the first and fifth pereiopods as buds, which become functional in the second zoeal stage, and the larval development consists of only 8-9 zoeal stages. The second pattern is represented by L. amboinensis (see Wunsch 1996), L. anchisteus (see Knowlton and Alavi 1995), L. vittata (see Yang 1999), and Kurata's (1970) L. wurdemanni: larvae hatch without buds and consequently, will have a longer zoeal development with a maximum of 11 zoeal stages. It appears that the distribution of larval developmental patterns among Lysmata species corresponds to the results currently available for the phylogenetic analysis of the genus; species with a long accessory branch when adults hatch with the first and fifth pereiopods as buds belong to the "Long Branch clade" (following Fiedler et al. 2010 nomenclature), while those species that hatch lacking buds of the first and the fifth pereiopods are included in the other clades. Table 2 presents the morphological characters relevant for staging the larvae of those Lysmata species which belong to the "Long Branch clade". It is commonly accepted that a pelagic mode of larval development with several larval stages represents a phylogenetically ancestral state in marine organisms, while shorter larval series are considered a derived character (Strathmann 1978; Anger 2001). In this way, the presented data on the larval development of Lysmata contribute to a better understanding of the phylogeny of the genus, with the species with long accessory branches and the first and fifth pereiopods as buds when hatching occupying a well resolved clade within the group.

The second zoeal stage of L. galapagensis presents a small protuberance in the dorsal region of the third pleomere, which in subsequent zoeal stages differentiates to a well defined anteriorly curved spine. This character is missing in all other larvae of Lysmata that have been studied. The late zoeal stages of L. galapagensis resemble, and may correspond to the material described as E. corniger for the eastern tropical Pacific by Gopalakrishnan and Laurs (1971): presence of an extremely long rostrum with several dorsal teeth, and a strong anteriorly curved spine on the dorsal surface of the third pleomere. Gurney's (1937) 
Table 1 Comparison of relevant morphological characters of the zoeal stages of L. seticaudata, L. galapagensis, and L. moorei

\begin{tabular}{|c|c|c|c|}
\hline Features & $\begin{array}{l}\text { L. galapagensis } \\
\text { present study (1); } \\
\text { Gopalakrishnan } \\
\text { and Laurs } 1971 \text { (2) }\end{array}$ & $\begin{array}{l}\text { L. moorei present } \\
\text { study }\end{array}$ & $\begin{array}{l}\text { L. seticaudata } \\
\text { Calado et al. } \\
2004\end{array}$ \\
\hline Distribution area & E Pacific & SW Atlantic & NE Atlantic \\
\hline Number of zoeal stages & $8-9$ & $8-9$ & 9 \\
\hline ZI, total length, mm & $2.46-2.89(1)$ & $2.77-2.81$ & $3.09-3.24$ \\
\hline $\mathrm{ZI}$, carapace length, mm & $0.92-1.00(1)$ & $0.92-0.96$ & $0.98-1.03$ \\
\hline $\mathrm{ZI}$, rostrum length, mm & $0.35-0.42(1)$ & 0.42 & 0.46 \\
\hline $\mathrm{ZIV}$, total length, mm & $4.14-4.63(1)$ & $3.44-3.66$ & $3.12-3.22$ \\
\hline ZIV, carapace length, mm & $1.61-2.15(1)$ & $1.13-1.29$ & $1.04-1.08$ \\
\hline $\mathrm{ZIV}$, rostrum length, $\mathrm{mm}$ & $0.92-1.35(1)$ & $0.54-0.70$ & 0.31 \\
\hline ZVII, total length, mm & $8.24-8.48(1)$ & NA & $4.47-4.79$ \\
\hline ZVII, carapace length, mm & $4.08-4.32(1)$ & NA & $1.40-1.56$ \\
\hline ZVII, rostrum length, mm & $2.80-3.04(1)$ & NA & $0.43-0.54$ \\
\hline Last $Z$, total length, $\mathrm{mm}$ & $16.10-20(2)$ & $7.81-9.35$ & $6.40-6.80$ \\
\hline Last $Z$, carapace length, mm & $2.12-3.40(2)$ & $3.85-4.84$ & $2.00-2.20$ \\
\hline Last $\mathrm{Z}$, rostrum length, $\mathrm{mm}$ & $6.13-7.00(2)$ & $2.31-3.19$ & $0.72-0.96$ \\
\hline \multicolumn{4}{|l|}{ Carapace } \\
\hline ZI, marginal denticles & $4(1)$ & $4-5$ & 6 \\
\hline ZIV, marginal denticles & $3-4(1)$ & $2-3$ & 3 \\
\hline ZVII, marginal denticles & $0(1)$ & NA & 0 \\
\hline Last, marginal denticles & $0(2)$ & 0 & 0 \\
\hline \multicolumn{4}{|l|}{ Rostrum } \\
\hline ZIV, number of spines & $5-6(1)$ & 0 & 0 \\
\hline ZVII, number of spines & $7(1)$ & NA & 0 \\
\hline Last, number of spines & $7-8(2)$ & $7-9$ & $1-2$ \\
\hline \multicolumn{4}{|l|}{ Antenna } \\
\hline Scaphocerite, absence of segments & ZIV (1) & ZIV & ZIV \\
\hline \multicolumn{4}{|l|}{ First pereiopod } \\
\hline Biramous bud/functional & ZI (1)/ZII (1) & ZI/ZII & ZI/ZII \\
\hline \multicolumn{4}{|l|}{ Second pereiopod } \\
\hline Very small biramous bud & ZII (1) & ZII & ND \\
\hline Biramous bud & ZIII (1) & ZIII & ZIII \\
\hline Functional & ZIV (1) & ZIV & $\mathrm{ZIV}$ \\
\hline \multicolumn{4}{|l|}{ Third pereiopod } \\
\hline Very small biramous bud & ZIV (1) & ZIV & ND \\
\hline Biramous bud & $\mathrm{ZV}(1)$ & NA & $\mathrm{ZV}$ \\
\hline Functional & ZVI (1) & NA & ZVI \\
\hline \multicolumn{4}{|l|}{ Fourth pereiopod } \\
\hline Very small biramous bud & - & NA & ND \\
\hline Biramous bud & ZV (1) & NA & $\mathrm{ZV}$ \\
\hline Functional & ZVI (1) & NA & ZVI \\
\hline \multicolumn{4}{|l|}{ Fifth pereiopod } \\
\hline Uniramous bud/functional & ZI (1)/ZII (1) & $\mathrm{ZI} / \mathrm{ZII}$ & $\mathrm{ZI} / \mathrm{ZII}$ \\
\hline \multicolumn{4}{|l|}{ Pleon } \\
\hline 3rd pleomere: dorsal anteriorly curved spine & ZIV-ZVII (1) & Absent & Absent \\
\hline 5th pleomere: one pair of dorso-lateral spines & ZI-ZV (1) & ZI-ZIV & ZI-ZII \\
\hline 5th pleomere: small dorsal spines & ZI: 3-4; ZII: 0-2; ZIII: 0 (1) & ZI: 3-4; ZII: 1-2; ZIII: 0 & Absent \\
\hline \multicolumn{4}{|l|}{ Pleopods } \\
\hline Small buds & ZVI (1) & NA & ZVI \\
\hline Biramous buds & - & NA & ZVII \\
\hline Endopod as bud, exopod with setae & ZVII (1) & NA & ZVIII \\
\hline With appendix interna & ZVIII (2) & Last (ZVIII or IX) & ZIX \\
\hline
\end{tabular}

$Z$ zoea, $N A$ not available in the larval series, $N D$ not developed 
Table 2 Larval development of Lysmata species belonging to the "Long Branch Clade"; staging based on larval morphological characters of the three species studies

\begin{tabular}{|c|c|}
\hline Larval stage & General morphological characters \\
\hline First zoea & $\begin{array}{l}\text { Eyes fused; one pterigostomial spine followed by } 4-6 \text { marginal denticles; rostrum long, slender and point- } \\
\text { ed. Scaphocerite } 5 \text {-segmented. Fifth pleomere with one pair of dorso-lateral spines. Pereiopods } 1 \text { and } 5 \\
\text { as buds. Telson with } 7+7 \text { plumose setae }\end{array}$ \\
\hline Second zoea & $\begin{array}{l}\text { Eyes stalked; antennal and supraorbital spines present; pterigostomial spine followed by marginal denti- } \\
\text { cles; rostrum long and slender with one postrostral spine. Pereiopods } 1 \text { and } 5 \text { developed and functional. } \\
\text { Telson with } 8+8 \text { plumose setae }\end{array}$ \\
\hline Third zoea & $\begin{array}{l}\text { Antennular peduncle } 2 \text {-segmented, inner and outer flagella present. Scaphocerite } 4 \text {-segmented. Sixth pleo- } \\
\text { mere separated from telson. Pereiopod } 2 \text { present as a biramous bud. Uropods present, with a rudimentary } \\
\text { endopod }\end{array}$ \\
\hline Fourth zoea & Scaphocerite unsegmented. Pereiopod 2 functional. Uropods exopods as long as telson \\
\hline Fifth zoea & $\begin{array}{l}\text { Biramous buds of pereiopods } 3 \text { and } 4 \text {. Uropods exopods longer than telson margin. Telson narrower at his } \\
\text { posterior end }\end{array}$ \\
\hline Sixth zoea & All pereiopods developed and functional. Pleopods present as small buds \\
\hline $\begin{array}{l}\text { Penultimate Zoea } \\
\text { (Seventh or Eighth) }\end{array}$ & $\begin{array}{l}\text { Antennal flagellum as long as scaphocerite with } 8 \text { segments. Biramous pleopods with endopods as buds and } \\
\text { exopods with apical setae }\end{array}$ \\
\hline Last Zoea (Eighth or Ninth) & $\begin{array}{l}\text { Antennal flagellum longer than scale with more than } 8 \text { segments. Pleopods with appendix interna. Telson } \\
\text { triangular with the migration of the first and second pairs of dorso-lateral spines almost concluded (telson } \\
\text { form almost similar to an adult) }\end{array}$ \\
\hline
\end{tabular}

Species A. V, Eretmocaris corniger, from the Atlantic Ocean, presents the same general form as L. galapagensis, however Gopalakrishnan and Laurs (1971) listed differences between the two species (Atlantic specimens: much smaller; one spine less on rostrum; three inner lobes on maxilla endopod; six setae less on basal enlargement of first maxilliped exopod; and first and second pereiopods not chelate). The penultimate stage of $L$. galapagensis described in present work is much smaller ( $\mathrm{TL}=8.24$ $8.48 \mathrm{~mm}$ ) than the last stage $(\mathrm{TL}=16.10-20.00 \mathrm{~mm})$ described by Gopalakrishnan and Laurs (1971). We suppose that L. galapagensis larvae in the last zoeal stage may pass through several instars which will enable them to grow without undergoing the morphological changes required to advance to decapodid. Lysmata larvae are well known for their ability to delay metamorphosis (Calado 2008), namely by performing mark-time molting, as defined by Gore (1985). In certain laboratory culture trials, Lysmata have persisted in the last zoeal stage for over 80 days (Palmtag and Holt 2007), molting several times without significant morphological changes but increasing in size. Therefore, the large size of the last zoea described by Gopalakrishnan and Laurs (1971) could be due to delayed metamorphosis.

Despite their similarity to L. galapagensis, larvae of L. moorei lack the unique morphological feature displayed by L. galapagensis on the third pleomere. Regardless of the close phylogenetic relationship suggested by the molecular studies by Baeza et al. (2009b), Baeza (2010) and Fiedler et al. (2010) between the eastern Pacific L. galapagensis and the western Atlantic L. moorei. The most evident larval character shared by the eastern Pacific L. galapagensis and the western Atlantic L. moorei is the presence of a very long rostrum with several teeth in late zoeal stages. Thus, the E. corniger larval forms found in the eastern Atlantic probably do not correspond to L. moorei. We suppose them to belong to an unknown Lysmata species that is phylogenetically closer to L. galapagensis than to L. moorei.

Biogeographical considerations on Eretmocaris corniger

L. galapagensis occurs in the eastern Pacific, but the most similar larvae known so far are those of Eretmocaris corniger collected in the eastern Atlantic. This geographical pattern suggests the existence of two distinct species which along with $L$. moorei might constitute a species complex. Gopalakrishnan and Laurs (1971) described E. corniger larvae from plankton of the eastern tropical Pacific Ocean and considered them to belong to a species of Lysmata associated with both the eastern Pacific (Galapagos) and the eastern Atlantic (Cape Verde) tropical islands. The Panama Isthmus is a geographic barrier formed three million years ago during the Pliocene, opened by the Panama Channel in 1914 , i.e. prior to the record of L. galapagensis in the eastern tropical Pacific by Schmitt (1924). However, there is little reason to believe that the Atlantic type might have dispersed to the Pacific Ocean after the opening of the Channel. The present paper matches the larvae of L. galapagensis with the E. corniger Pacific type, and Gopalakrishnan and Laurs (1971) presents consistent differences between this and the E. corniger Atlantic type. It is 
assumed that present populations of some coastal decapod crustaceans from the eastern Atlantic, western Atlantic, and eastern Pacific are genetically isolated from each other (e.g. Schubart et al. 2005). Knowlton et al. (1993) suggested that some of the studied species of the snapping shrimp Alpheus may have diverged before the final closure of the Panama seaway, in a staggered model. Also, Schubart et al. (2005) stated that the Atlantic and Pacific forms of the Pachygrapsus transversus complex diverged prior to the closure of the Isthmus of Panama, recognizing that the eastern Pacific population is in fact a valid species, $P$. socius. The larvae of tropical shrimp are capable of long-distance dispersal (Goy 1990), and this might result in a circumtropical distribution of many shrimp species, implying that speciation is mainly sympatric. However, the very recent work by Rhyne et al. (2009a) suggested that this potential for larval dispersal is unrealized and that there is a strong reproductive isolation. In fact, no species of the genus Lysmata has been recorded for both the Pacific and Atlantic Oceans. Of the closest related species once thought to occur in both of these oceans, has been split in two: L. grabhami is an amphiAtlantic species, and L. amboinensis known to occur from the western tropical Indian Ocean to the Hawaiian Islands but absent from the eastern tropical Pacific (Debelius 2001). Considering that L. galapagensis and E. corniger Atlantic type share the special character of the third pleomere which is absent in L. moorei, the most plausible scenario is as follows: The eastern Atlantic E. corniger corresponds to the larval form of a probably still undescribed Lysmata species. This species, formerly distributed on either side of the Atlantic, might have formed a transisthmian complex with L. galapagensis (or a common ancestor), but is now restricted to the eastern Atlantic. Phylogenetically, this undescribed species might be closer to L. galapagensis than L. moorei. Future efforts to identify the adult form of Atlantic E. corniger should focus on the larval culture of Lysmata species, which are morphologically and/or molecularly close to L. galapagensis and are known to occur at oceanic islands in the eastern Atlantic.

\section{Biodiversity and conservation issues}

The current fishing pressure on ornamental shrimp of the genus Lysmata has dramatically increased in recent years (Rhyne et al. 2009b), and this has lead researchers and policy makers to question the sustainability of this practice and to start monitoring potential ecological impacts of this commercially profitable activity (e.g. Calado 2008). The correct identification of taxa in their larval form is essential to estimate populations, their connectivity, recruitment, and spatiotemporal distributions (e.g. Levin 2006; Rhyne et al. 2009a). This highlights the need to identify the adult forms of known Eretmocaris and to describe the complete larval series of Lysmata species.

Understanding larval dispersal is vital to a successful management of any kind of commercial fishery (e.g. dos Santos 1998; Calado 2008; Marta-Almeida et al. 2008) as well as to an establishment of marine nature reserves and/or no-take areas (e.g. Almany et al. 2009; Planes et al. 2009). This requires a solid knowledge of the larval stages of target species which commonly is either incomplete or missing even for well-studied regions such as the northeastern Atlantic (González-Gordillo et al. 2001). Although some progress has been made in the identification of larval stages using molecular tools (e.g. Pan et al. 2008; Jones et al. 2009), classical larval morphological descriptions are far from being obsolete. In fact, small intraspecific variations in larval morphology induced by environmental gradients (Schubart et al. 2005) will certainly be detected only by classical approaches. An additional challenge is the occurrence of co-occurring cryptic species (Rhyne and Lin 2006), which might be more common than initially assumed (Baeza et al. 2009b).

Acknowledgments The authors would like to thank to Helio Laubenheimer and Raul Marinheiro for rearing the larvae of L. moorei. CB is supported by Fundação para a Ciência e a Tecnologia (FCT) through the postdoctoral fellowship SFRH/BPD/63888/2009. The anonymous referees and Prof. Dr. Heinz-Dieter Franke provided helpful comments that improved the quality of the manuscript.

\section{References}

Almany GR, Connolly SR, Heath DD, Hogan JD, Jones GP, McCook LJ, Mills M, Pressey RL, Williamson DH (2009) Connectivity, biodiversity conservation and the design of marine reserve networks for coral reefs. Coral Reefs 28:339-351

Anger K (2001) The biology of decapod crustacean larvae. Crustacean issues 14. A.A. Balkema, Lisse

Anker A, Baeza JA, De Grave S (2009) A new species of Lysmata (Crustacea, Decapoda, Hippolytidae) from the Pacific coast of Panama, with observations of its reproductive biology. Zool Stud 48:682-692

Baeza JA (2010) Molecular systematics of peppermint and cleaner shrimps: phylogeny and taxonomy of the genera Lysmata and $E x$ hippolysmata (Crustacea: Caridea: Hippolytidae). Zool J Linn Soc 160:254-265

Baeza JA, Bolanos JA, Hernandez JE, Lopez R (2009a) A new species of Lysmata (Crustacea, Decapoda, Hippolytidae) from Venezuela, southeastern Caribbean Sea. Zootaxa 2240:60-68

Baeza JA, Schubart CD, Zillner P, Fuentes S, Bauer RT (2009b) Molecular phylogeny of shrimps from the genus Lysmata (Caridea: Hippolytidae): the evolutionary origins of protandric simultaneous hermaphroditism and social monogamy. Biol J Linn Soc 96:415-424

Bate CS (1888) Crustacea Macrura. Challenger Reports, Zool, p XXIV Brightdoom M, Marín B, Zoppi E, Moreno C (2006) Zooplancton del Golfo Cariaco. Bol Inst Ocean Venezuela Univ Oriente 45:61-78

Calado R (2008) Marine ornamental shrimp-biology, aquaculture and conservation. Wiley-Blackwell, Oxford 
Calado R, Lin J, Rhyne AL, Araújo R, Narciso L (2003a) Marine ornamental decapods- popular, pricey, and poorly studied. J Crust Biol 23:963-973

Calado R, Narciso L, Morais S, Rhyne AL, Lin J (2003b) A rearing system for the culture of ornamental decapod crustacean larvae. Aquaculture 218:329-339

Calado R, Bartilotti C, Narciso L, dos Santos A (2004) Redescription of the larval stages of Lysmata seticaudata (Risso, 1816) (Crustacea, Decapoda, Hippolytidae) reared under laboratory conditions. J Plank Res 26:737-752

Caroli E (1918) Miersia clavigera Chun, stadio misidiforme di Lysmata seticaudata Risso. Pubbl Staz Zool Napoli 2:177-189

Clark PF (2009) The bearing of larval morphology on brachyuran phylogeny. In: Martin JW, Crandall KA, Felder DL (eds) Decapod Crustacean Phylogenetics. Crustacean Issues 18:221-241

Clark PF, Calazans DK, Pohle GW (1998) Accuracy and standardization of brachyuran larval descriptions. Invertebr Reprod Dev 33:127-144

Debelius H (2001) Crustacea guide of the world. IKAN-Unterwasserarchive, Frankfurt

dos Santos A (1998) On the occurrence of larvae of Parapenaeus longirostris (Crustacea: Decapoda: Penaeoidea) off the Portuguese coast. J Nat Hist 32:1519-1523

Fiedler GC, Rhyne AL, Segawa R, Aotsuka T, Schizas NV (2010) The evolution of euhermaphroditism in caridean shrimps: a molecular perspective of sexual systems and systematics. BMC Evol Biol 10:297

Garm A (2004) Mechanical functions of setae from the mouth apparatus of seven species of decapod crustaceans. J Morphol 260:85-100

González-Gordillo JI, dos Santos A, Rodríguez A (2001) Checklist and annotated bibliography of decapod crustacean larvae from the South western European coast (Gibraltar Strait area). Sci Mar 65:275-305

Gopalakrishnan K, Laurs RM (1971) Eretmocaris corniger Bate larvae from the Eastern Tropical Pacific Ocean (Caridea, Hippolytidae). Crustaceana 20:9-18

Gore RH (1985) Molting and growth in decapod larvae. In: Wenner AM (ed) Crustacean Issues 2:1-65

Goy JW (1990) Components of reproductive effort and delay of larval metamorphosis in tropical marine shrimp (Crustacea: Decapoda: Caridea and Stenopodidae). PhD thesis, Texas A\&M University, USA

Gurney R (1937) Larvae of decapod crustacea. Part IV. Hippolytidae. Disc Rep 14:351-404

Jones GP, Almany GR, Russ GR, Sale PF, Steneck RS, Van Oppen MJH, Willis BL (2009) Larval retention and connectivity among populations of corals and reef fishes: history, advances and challenges. Coral Reefs 28:307-325

Knowlton RE, Alavi MR (1995) The larval morphology of Lysmata anchisteus Chace (Crustacea: Decapoada) compared with other Lysmata spp. Caribb J Sci 31:289-310

Knowlton N, Weigt LA, Solórzano LA, Mills DK, Bermingham E (1993) Divergence in proteins, mitochondrial DNA, and reproductive compatibility across the Isthmus of Panama. Science 260:1629-1632

Kurata H (1970) Studies on the life histories of Decapod Crustacea of Georgia. PhD thesis, University of Georgia, USA
Laubenheimer H, Rhyne AL (2010) Lysmata rauli, a new species of peppermint shrimp (Decapoda: Hippolytidae) from the southwestern Atlantic. Zootaxa 2372:298-304

Levin LA (2006) Recent progress in understanding larval dispersal: new directions and digressions. Integr Comp Biol 46:282-297

Lindley JA, Hernández F, Tejera E, Jiménez S (2002) An unusual pinnotherid zoea attributed to Afropinnotheres monody Manning, 1993 (Decapoda: Brachyura: Pinnotheridae) from the Selvagens Islands (Eastern Atlantic Ocean). Bocagiana 205:1-5

Marta-Almeida M, Dubert J, Peliz Á, dos Santos A, Queiroga H (2008) A modelling study of Norway lobster (Nephrops norvegicus) larval dispersal in southern Portugal: predictions of larval wastage and self-recruitment in the Algarve stock. Can J Fish Aq Sci 65:2253-2268

Palmtag MR, Holt GJ (2007) Experimental studies to evaluate larval survival of the fire shrimp, Lysmata debelius, to the juvenile stage. J World Aquac Soc 38:102-113

Pan M, McBeath AJA, Hay SJ, Pierce GJ, Cunningham CO (2008) Real-time PCR assay for detection and relative quantification of Liocarcinus depurator larvae from plankton samples. Mar Biol 153:859-870

Pillai SV (1974) Laboratory reared larval forms of Hippolysmata (Exhippolysmata) ensirostris Kemp (Decapoda: Hippolytidae). J Mar Biol Ass India 16:594-608

Planes S, Jones GP, Thorrold SR (2009) Larval dispersal connects fish populations in a network of marine protected areas. Proc Natl Acad Sci USA 106:5693-5697

Rhyne AL, Lin J (2006) A western Atlantic peppermint shrimp complex: redescription of Lysmata wurdemanni, description of four new species, and remarks on Lysmata rathbunae (Crustacea: Decapoda: Hippolytidae). Bull Mar Sci 79:165-204

Rhyne AL, Zhang D, Lin J, Schizas NV (2009a) Not any two will do: DNA divergence and interpopulation reproductive compatibility in a simultaneous hermaphroditic shrimp Lysmata wurdemanni. Mar Ecol Prog Ser 388:185-195

Rhyne A, Rotjan R, Bruckner A, Tlusty M (2009b) Crawling to collapse: ecologically unsound ornamental invertebrate fisheries. PLoS ONE 4(12):e8413

Schmitt WL (1924) Bijdragen tot de kennis der fauna van Curaçao. Resultaten eener reis van Dr. C. J. van der Horst in 1920. The macruran, anomuran and stomatopod Crustacea. Bijdr Dierkd 23:61-81

Schubart CD, Cuesta JA, Felder DL (2005) Phylogeography of Pachygrapsus transversus (Gibbes, 1950), the effect of the American continent and the Atlantic Ocean as gene flow barriers and recognition of Pachygrapsus socius Stimpson 1871 as a valid species. Nauplius 13:99-113

Strathmann RR (1978) The evolution and loss of feeding larval stages of marine invertebrates. Evolution 32:894-906

Wunsch M (1996) Larval development of Lysmata amboinensis (De Man, 1888) (Decapoda: Hippolytidae) reared in the laboratory with a note on L. debelius (Bruce, 1983). MSc thesis, University of Wales, UK

Yang HJ (1999) Larval development of eight species of alpheoid shrimps (Decapoda, Caridea, Alpheoidea) reared in the laboratory. PhD thesis, Pusan National University, Korea 